\title{
Leopard spots, chequerboards and spider's webs: classification, systematics and function of variegated leaves in Orchidaceae
}

\author{
Schuiteman A. \\ Royal Botanic Gardens, Kew, Richmond, Surrey, TW9 3AB, UK \\ E-mail: a.schuiteman@kew.org
}

\begin{abstract}
A list of 800 orchid species with variegated leaves from 101 genera is presented. Their modes of variegation are classified using a simple scheme of five elements. The systematic occurrence of variegation is tabulated and analysed, and the potential ecological functions of variegation are discussed.
\end{abstract}

Keywords: Camouflage, Jewel orchids, Leaf markings, Mimicry, Variegation.

\section{Introduction}

Orchids are best known for the extraordinary diversity of their flowers. It is fair to say that this has overshadowed the hardly less remarkable diversity of their vegetative parts. One aspect that has so far received little attention in the literature is the extensive variety in leaf markings (variegation) present in this family. For example, leaf variegation is mentioned only in passing in Dressler's admirable introduction to the orchid family (Dressler, 1981). Orchid amateurs know about 'jewel orchids', species with exquisitely marked leaves, that are mainly cultivated for their attractive foliage (Fig. 1). Most of these belong to certain genera in subtribe Goodyerinae, such as Anoectochilus Blume, Goodyera R.Br., and Ludisia Rich. Perhaps a few dozen species are regularly seen in cultivation.

The phenomenon of leaf variegation in Orchidaceae is far more extensive than the limited number of cultivated jewel orchids would suggest.

Received: 29.03.2021; Revised \& Accepted: 28.05.2021

Published Online: 16.10.2021
In a recent overview paper on leaf variegation in angiosperms, Zhang et al. (2020) enumerated 252 orchid species in 42 genera out of a total of 1710 species of flowering plant. This makes Orchidaceae the largest family in their sample. It remains to be seen if orchids will keep this leading position if all flowering plant species are considered. However, it can already be stated that the number of variegated orchids is far greater than 252. As reported here, at least 800 species in 101 genera have variegated leaves of some kind (see Appendix). This translates to approximately $3 \%$ of the species and $14 \%$ of the genera of Orchidaceae. To put this in perspective, Zhang et al. (2020) list only 15 variegated species, or $0.06 \%$, in the roughly equally large family Asteraceae.

Leaf markings in orchids occur in numerous forms. Many of the jewel orchids already mentioned have an intricate web of silvery, golden or red veins on a velvety, deep bronze to blackish background. In other variegated orchids we find spots, small or large, arranged randomly or in regular patterns. They may resemble a leopard's skin, a chequerboard, a cloudy sky, a piece of granite, and various other things. There can be bold longitudinal bands and even transverse stripes. The leaf colour often deviates from the standard plain green and may exhibit, for example, shades of brown or purple.

In this paper, the various kinds of foliar variegation in orchids are described and illustrated, their systematic occurrence is examined, and their 


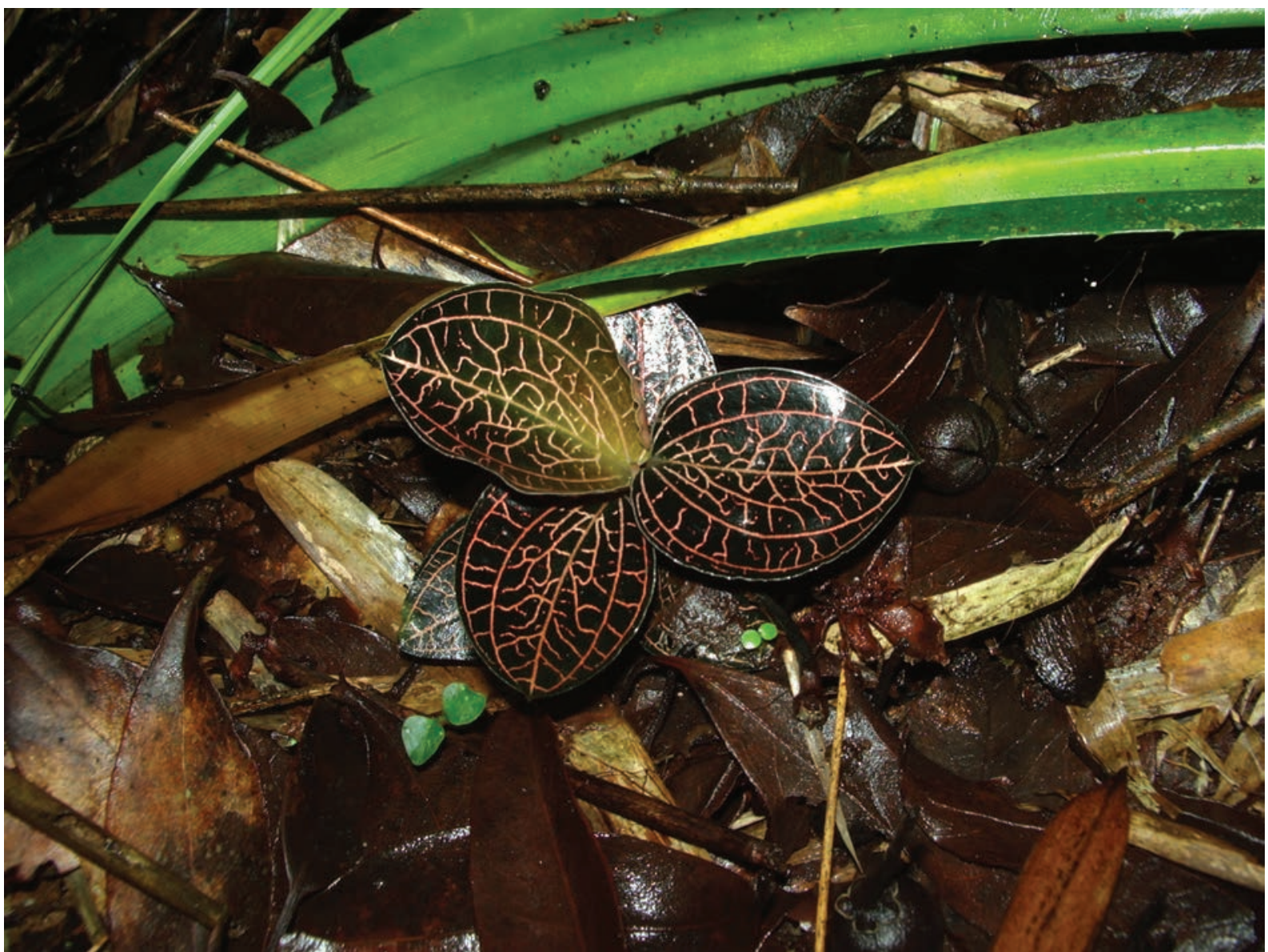

Fig. 1. A jewel orchid, Anoectochilus reinwardtii Blume, in situ, Java (photo by André Schuiteman).

ecological significance discussed. For brevity's sake, orchids with variegated leaves will be referred to simply as variegated orchids.

\section{Materials and Methods}

For the purpose of this paper, a variegated leaf is defined as one that has an adaxial (upper) surface that is not plain green and/or has spots or stripes anywhere on the leaf blade. Leaves that only have markings on the (pseudo-)petiole or on the sheathing basal part are not included (e.g., the transverse brown stripes on the leaf bases of Habenaria pseudociliosa Schelpe ex J.C.Manning or the purple spots on the sheathing part of the leaf of several otherwise unspotted Paphiopedilum Pfitzer species). Cataphylls of young growths can have striking spots and bands, but they too fall outside the scope of this paper. Also excluded are species where only the abaxial side of the leaf is non-green but not striped or spotted. These cases are excluded because they would vastly increase the number of species to consider and, more importantly, available data would be far scarcer. In many orchid species, the young leaves are not green and often also marked with stripes and spots (Fig. 2a \& b), but as the leaf matures it soon becomes plain green and the markings disappear. Such species, which are hardly ever reported but are not uncommon, are not included either. Lev-Yadun (2016) has suggested that the different colours of abaxial versus green adaxial leaf surfaces as well as non-green young leaves serve to impede the camouflage of green herbivorous insects.

Orchids with strongly pruinose leaves, such as Prosthechea citrina (Lex.) W.E.Higgins and Masdevallia caesia Roezl, are not considered to be variegated. As an aside, it is interesting to note that several of such orchids have pendulous leaves, 


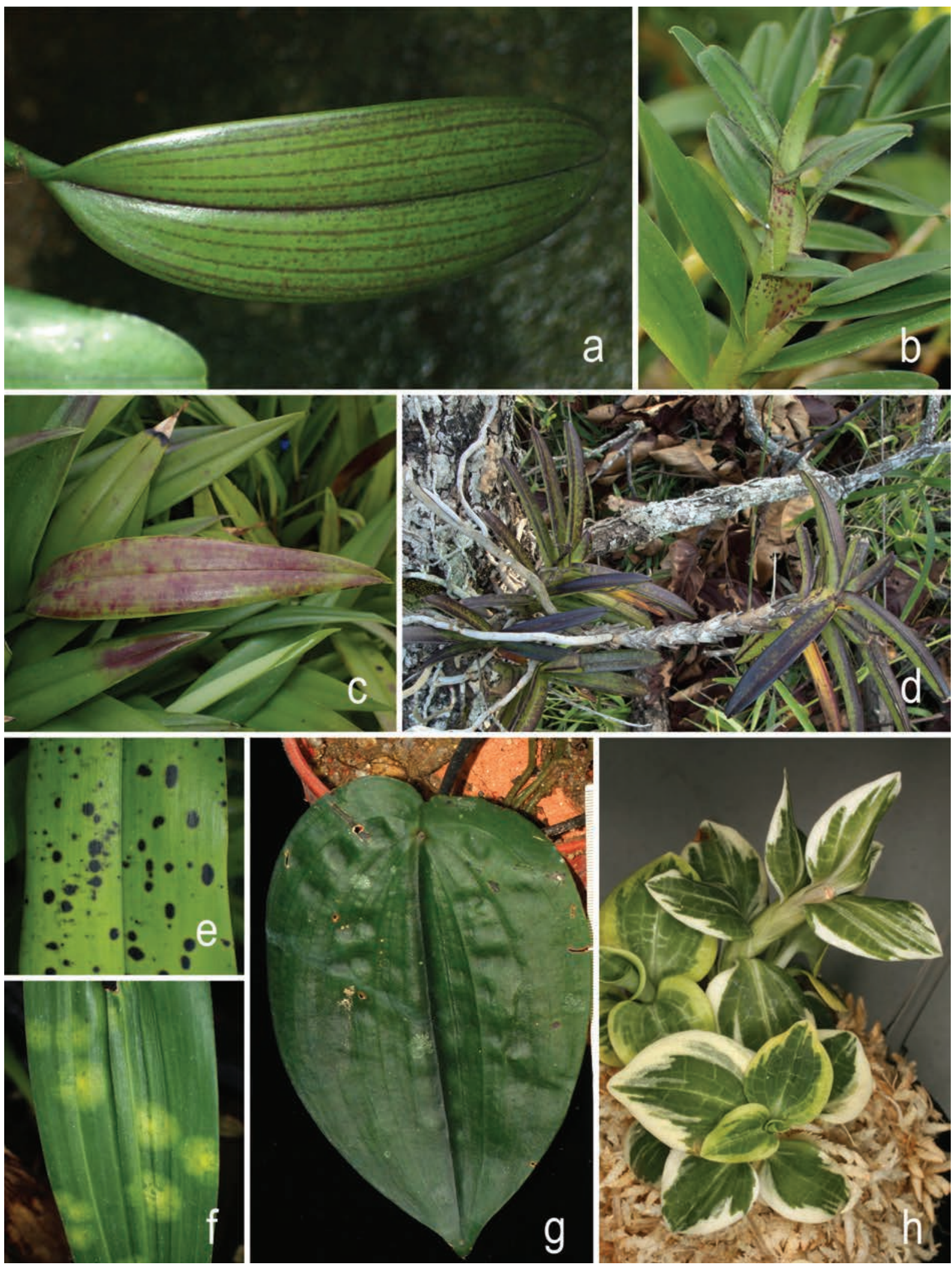

Fig. 2. Phenomena not considered in this paper. (1) Ephemeral markings in developing leaves: a. Bulbophyllum bisetum Lindl. (cult.); b. Maxillaria sp. (cult.); (2) Purple colouring due to stress or high light levels: c. Octomeria grandiflora Lindl. (cult.); d. Vanda miniata (Lindl.) L.M.Gardiner (in situ, Cambodia); (3) Markings caused by pests and diseases: e. \& f. (undiagnosed, both cult.); (4) 'pseudo-markings' caused by 3dimensional textures: g. Tainia crassa (H.Turner) J.J.Wood \& A.L.Lamb (cult.); (5) Horticultural variegation: h. Goodyera schlechtendaliana 'Hatsuyume' (photo g by Peter O'Byrne, h by Henry Oakeley, all others by André Schuiteman). 
suggesting a shared adaptation (possibly to prevent mosses and lichens from colonizing the leaves). Numerous plants, including orchids, develop a purple tinge in the leaves in response to high light intensities or stress (Gould et al., 2002), and this may take the form of spots and stripes and can even extend to the whole leaf surface (Fig. 2c \& d). Leaves of the same plant, or the same plant at a different time of year, may be plain green, and such species are not included here. Also excluded are species with leaves that are only marked because of disease and attacks by pests (Fig. 2e \& f).

The effects of some types of variegation can be simulated by variation in the 3-dimensional relief of the leaf. Striking, large, round 'dimples' are common in certain species of Tainia Blume (Fig. $2 \mathrm{~g}$ ) and their shadows resemble round spots; some Nervilia species have sharp folds along the veins, simulating a banding pattern, and some orchids, such as Peristylus pachyneurus (Schltr.) P.F.Hunt, have raised veins that produce a pattern of light and shade resembling reticulation. It is possible that these structural patterns perform the same ecological function as actual variegations. Finally, variegation as seen in selected clones in horticulture, usually manifesting itself as white longitudinal bands or patches lacking chlorophyll, will not be considered in this paper (Fig. 2h).

Although most examples of variegation are obvious (Figs. 3-9, 11-14), there are, inevitably, debatable cases. No leaf is entirely uniformly green; veins are usually slightly darker or lighter than the surrounding tissue, and under high magnification various epidermal colour patterns may emerge. Here, only macroscopic patterns displayed in visible light are included, but this still leaves room for debate. For example, in most species of Rhynchostylis Blume the leaves have light green main veins (Fig. $5 \mathrm{~g}$ ), but these are not nearly as striking as those in some of the jewel orchids. Rhynchostylis is nevertheless included because the light veins are not seen in any of the related genera and are, therefore, noteworthy, but it is hardly a textbook case of variegation.
This study would hardly have been feasible preinternet. Next to living plants, colour photographs are the most useful evidence for leaf variegation, and there is no shortage of orchid photographs on the internet. Google image search has been invaluable, as have been various on-line herbaria (AMES, K, L, P, and $\mathrm{PE}$ have all been accessed frequently) and several orchid websites (e.g., www.orchidspecies.com and http://www.orchidsnewguinea.com/). It goes without saying that identifications were approached with scepticism, in that genus identifications were always verified, and, depending on the source, species identifications were often double-checked.

First, a basic list was compiled of genera that were commonly known to have variegated species. Next, various well-illustrated books on regional orchid floras were consulted and more species and genera were added as a result. For the remaining genera, a sample of species was checked for the presence of variegated leaves. Genera with a significant proportion of variegated species were browsed in the on-line herbaria just mentioned. Although variegation is not always visible in herbarium material, it usually is, and collector's labels often contain indications about leaf markings (but not as often or as detailed as one would wish). Lists of species to check in the literature were prepared using Govaerts et al. (2021) and Plants of the World Online (POWO, 2021). Of genera with only few variegated species (e.g., Epidendrum L.) many online images were evaluated and if no additional variegated species turned up, these genera were not investigated further. In genera with many variegated species, such as Goodyera, most of the protologues of species not seen in online herbaria and not described in floristic works were retrieved from the invaluable Biodiversity Heritage Library (BHL, 2021). Protologues often make no mention of leaf variegation even if the species are variegated, and the law of diminishing returns has limited the number of species that were checked by consulting the protologue in a physical copy of the publication. Inevitably, some 


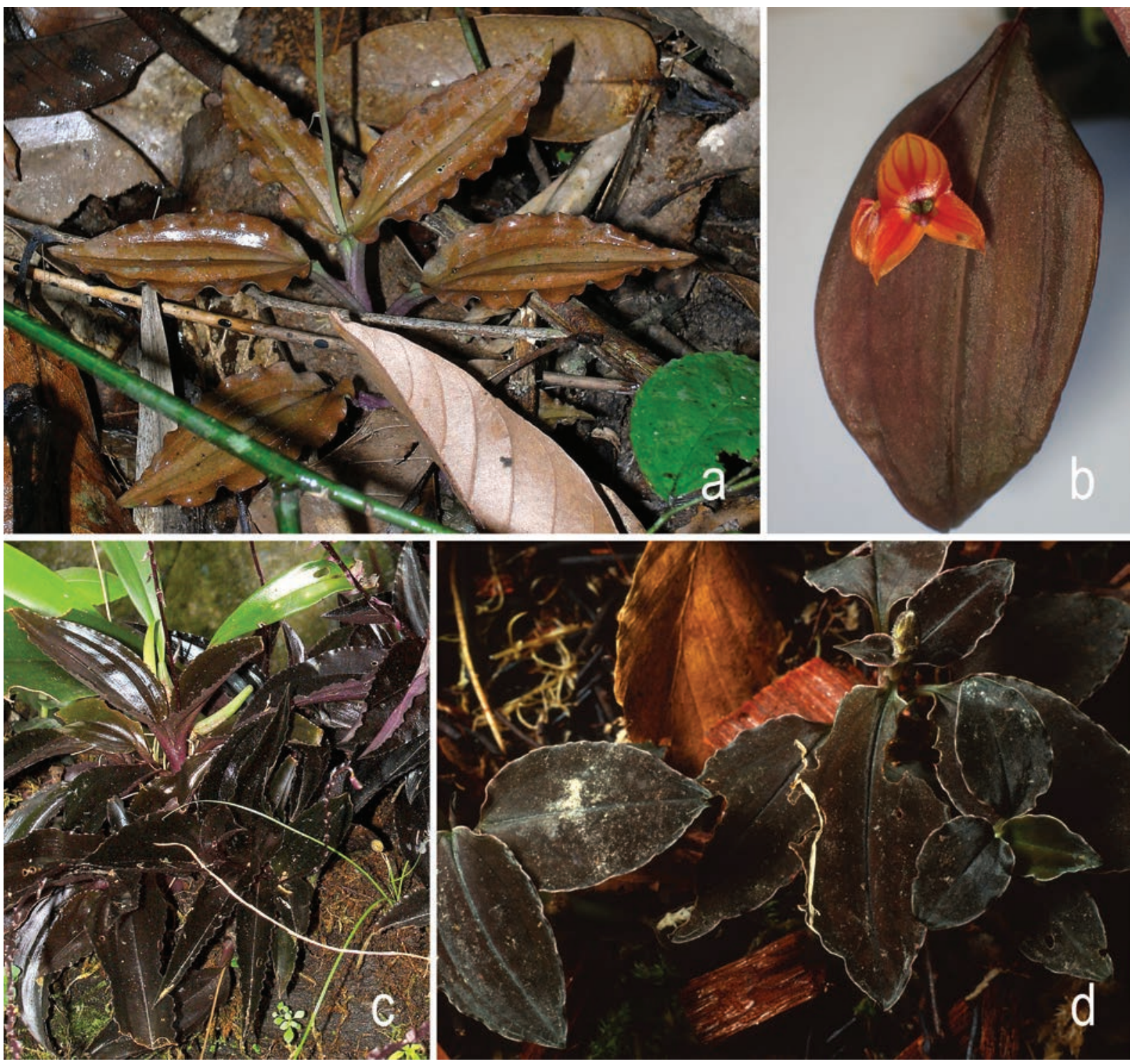

Fig. 3. Leaves with non-green ground colour: a. Crepidium micranthum (Hook.f.) Szlach. (in situ, Malaysia); b. Lepanthes niesseniae Luer (cult.); c. Crepidium metallicum (Rchb.f.) Szlach. (in situ, Sabah); d. Cystorchis cf. javanica (Blume) Blume (cult.) (photos a \& c by Peter O’Byrne, $b$ \& d by André Schuiteman).

species that could have been included must have been overlooked.

It is not likely that a high percentage of species with variegated leaves were missed, but in some genera the low number of available illustrations and lack of adequate label data make it plausible that they contain several or even many more unreported variegated species, particularly in Cheirostylis Blume, Cranichis Sw., Cynorkis Thouars, Habenaria Willd., Microchilus C.Presl, Nervilia Comm. ex Gaudich., Pelexia Poit. ex Rich., Sarcoglottis C.Presl, Zeuxine Lindl., and various genera in the
Pleurothallidinae, especially Acianthera Scheidw. and Lepanthes Sw.

Nomenclature usually follows Govaerts et al. (2021), with very few exceptions, mainly in cases where the latter was not yet up to date at the time of consultation. Phaius Lour. is here included in Calanthe R.Br. (Chase et al., 2020), Oeceoclades Lindl. in Eulophia R.Br. ex Lindl. (Chase et al., 2021). New World Goodyerinae were updated following Smidt et al. (2021). For European orchids, Kühn et al. (2019) have been followed. 

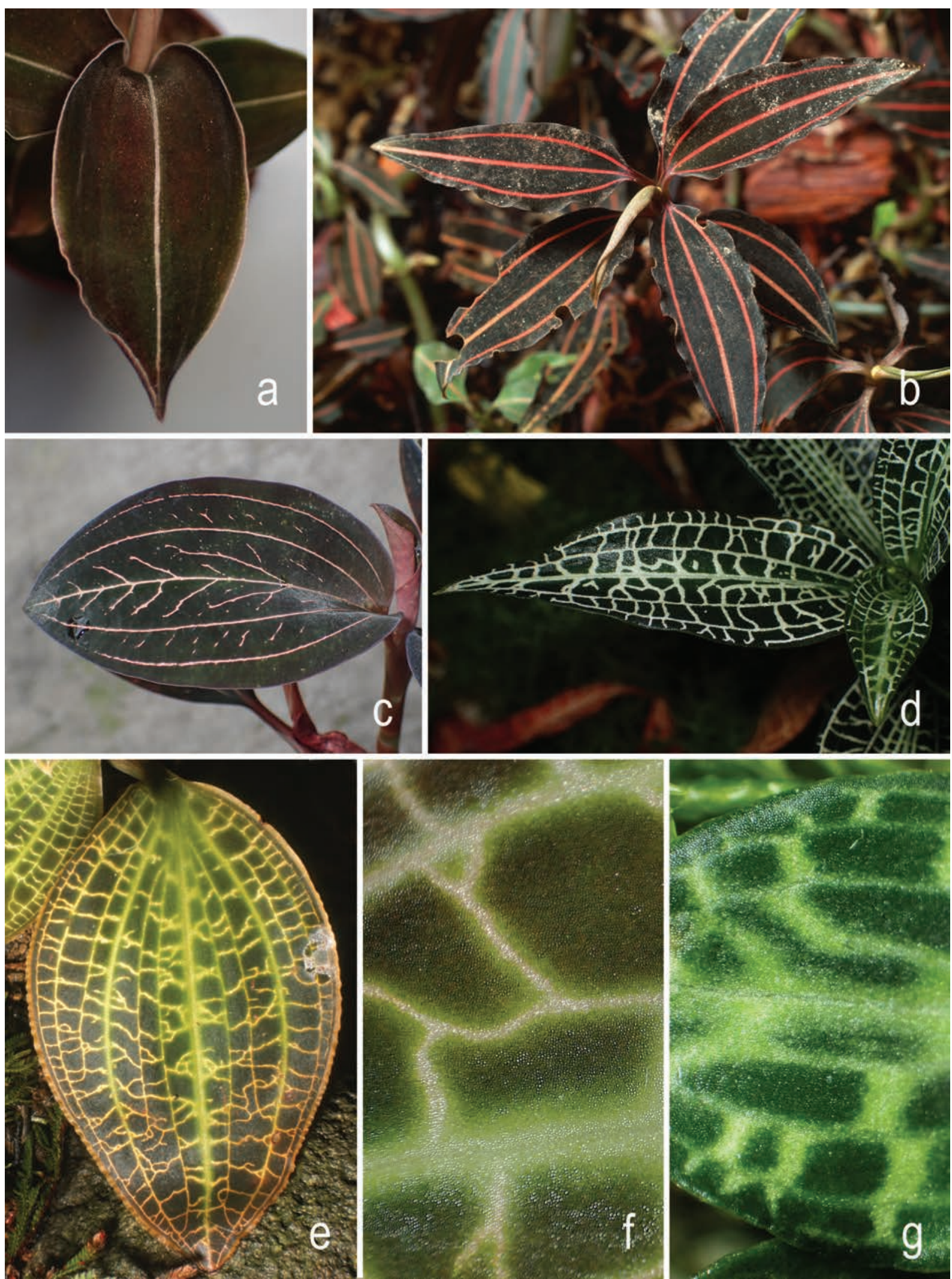

Fig. 4. Leaves with conspicuous veins: a. Bidoupia phongii Aver., Ormerod \& Duy (cult.); b. Vrydagzynea tristriata Ridl. (cult.); c. Ludisia discolor (Ker Gawl.) Blume (cult.); d. Goodyera hispida Lindl. (cult.); e. Macodes sanderiana (Kraenzl.) Rolfe (cult.); f. Macodes sanderiana (cult.), detail of veins, showing marginal banding; g. Goodyera schlechtendaliana Rchb.f. (cult.), showing bar-like markings along the crossveins (photos by André Schuiteman). 


\section{Anatomy and types of variegation}

Anatomically, variegation in leaves is mostly due to one of four factors or a combination thereof (Hara, 1957; Zhang et al., 2020): 1. Chlorophyll deficiency (lower number of chloroplasts or reduced production of chlorophyll); 2. Presence of intercellular spaces; 3 . Presence of non-green pigments; 4. Special epidermal cell structures. The last-mentioned has apparently not yet been reported from orchids, 1. is very rare (Zhang et al., 2020, only listed Bulbophyllum reticulatum Bateman ex Hook.f. (Fig. 5f) among 252 orchids), and 2. and 3. appear to be by far the most frequent (Zhang et al., 2020). Intercellular spaces cause an increase in light reflectivity (Sheue et al., 2012) and patches of leaves with tissue rich in intercellular spaces appear lighter, often even silvery. The density of functional chloroplasts underneath such tissue is usually not different from that in other parts of the leaf, and this is clearly seen when the leaf is observed in transmitted light: the lighter patches stand out far less in transmitted light than in reflected light (Fig. 6e \& f). Another type of variegation, which is not covered by Hara's four factors mentioned above, is only known from two species of Maxillaria Ruiz \& Pavón; here, striking white spots are produced by epicuticular wax deposits (Fig. 7c), which at least in M. pseudoreichenheimiana Dodson can be rubbed off with some effort. It has been asserted (http://www.orchidspecies.com/ maxpseudoreichenheimiana. htm) that in the similar M. reichenheimiana Endrés \& Rchb.f. the spots cannot be rubbed off, but this requires confirmation.

Many variegated orchids, especially in Goodyerinae, have a velvety-matt epidermis caused by conical cuticular cells, which are often said to focus light into the mesophyll, as an adaptation to low light levels (Poobathy et al., 2018), but Brodersen \& Vogelmann (2007) found no evidence that lens-shaped epidermal cells increased the capture of diffuse light, and their function remains unclear. The very dark, almost blackish colour of the leaves of certain species in this group is caused by abaxial cell layers rich in anthocyanins underneath the palisade mesophyll, which contains chloroplasts (Poobathy et al., 2018), and the epidermal structure just mentioned makes them appear even darker.

The spatial patterns produced by variegation are manifold and not always easy to describe. Zhang et al. (2020) have recently proposed a new classification of leaf variegation into seven basic types. Unfortunately, even if we only consider orchid leaves, reality is too complex to be shoehorned into just seven types. For example, one of the types distinguished by Zhang et al. is "Reticulate: Non-green areas interwoven along the main vein, the first lateral veins and the second lateral veins." In Ludisia discolor, one can find plants with only the mid-vein non-green (silvery, golden or red), or with the three main veins non-green, or with in addition some of the branches of the main veins non-green (Fig. 4c). Only the latter would presumably qualify as 'Reticulate', the others would be called 'Striped' under this classification - an artificial distinction. Similar unnatural distinctions are made between spots (round) and blotches (not round). A modified definition of spots and blotches is used below. What these authors confusingly call the 'Fishbone' pattern (it does not resemble a fishbone, whereas their 'Pinnate' pattern does) includes cases where patterns are formed by nongreen veins, which could also fall under 'Reticulated'. For these reasons this classification was not adopted in the present study.

Instead of identifying a limited number of patterns that do not match all possibilities, variegation patterns are here classified based on a set of elements that underlie each pattern, and the pattern is then characterized as the particular combination of these elements.

At the most basic level, there are just two elements involved in variegation: patches and lines (usually corresponding to the veins). However, this should be refined to make a more detailed classification possible. For this study, where often only limited information was available about variegation 

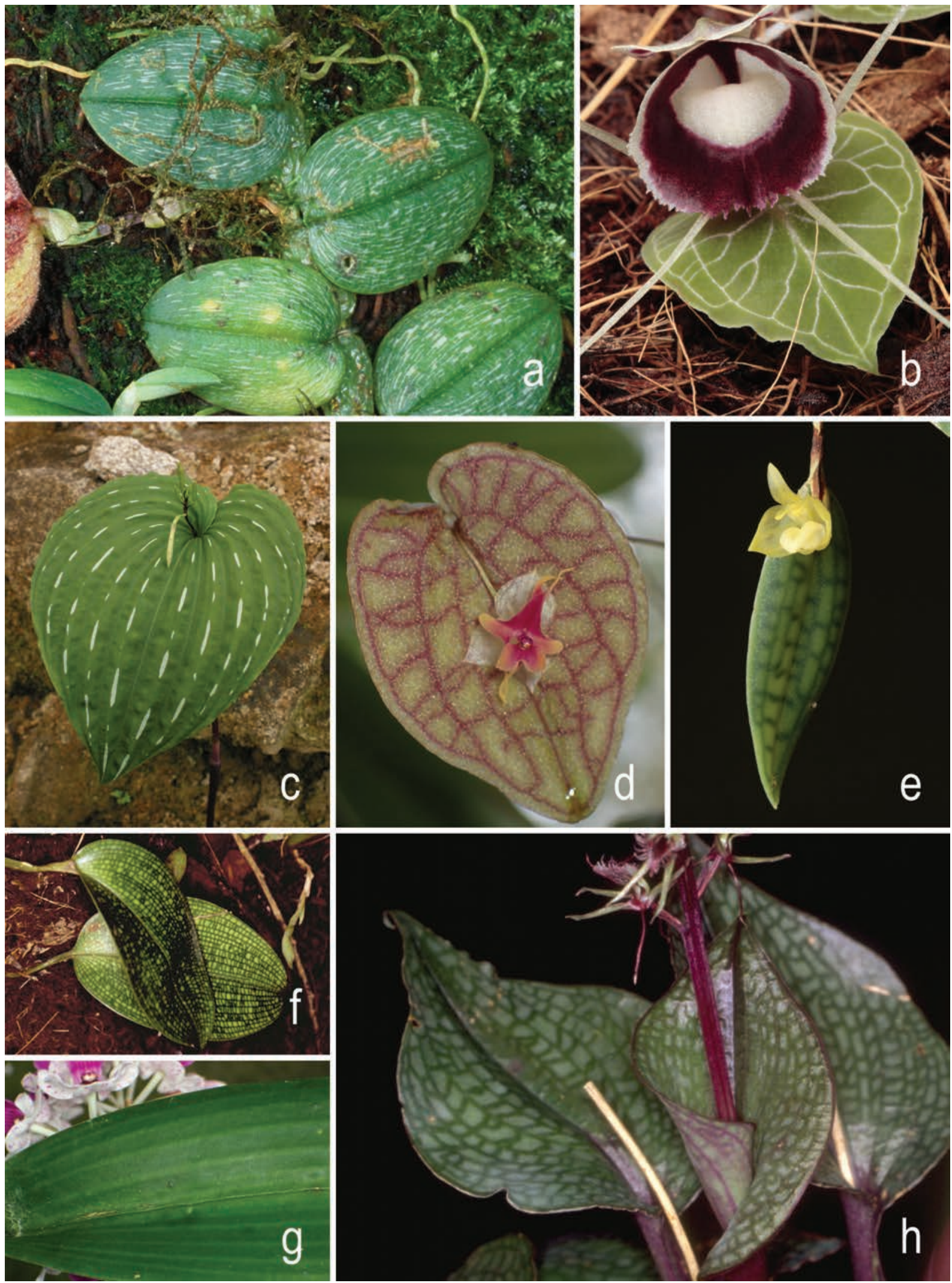

Fig. 5. Leaves with conspicuous veins: a. Bulbophyllum caputgnomonis J.J.Verm. (cult.); b. Corybas pictus (Blume) Rchb.f. (cult.); c. Monophyllorchis microstyloides (Rchb.f.) Garay (in situ, Ecuador); d. Lepanthes saltatrix Luer \& Hirtz (cult.); e. Bulbophyllum lygeron J.J.Verm. (cult.); f. Bulbophyllum reticulatum Bateman ex Hook.f. (in situ, Sarawak); g. Rhynchostylis gigantea (Lindl.) Ridl. (cult.); h. Liparis purpureoviridis Ridl. ex Burkill \& Holttum (photos a by Peter Jongejan, c by Henry Oakeley, $f$ \& h by Peter O'Byrne, all others by André Schuiteman). 
patterns, the following five elements provided useful distinctions. They are identified by a letter which is also used in the species list in the Appendix. $\mathbf{N}$ A non-green ground colour on the adaxial surface. Orchids with variegated leaves frequently not only have striking veins or spots but also an unusual ground colour on the adaxial side of the leaf, such as dark maroon, bronze, light brown, purple, silvery grey, etc. Extremely pale or extremely dark shades of green are also classified as non-green. Orchids with uniformly non-green leaves but without other markings are still classified as variegated here (Fig. 3). This seems reasonable, because with few exceptions (e.g., in Coelogyne Lindl.), the 73 species with uniformly non-green leaves listed here are closely related to those that have obvious markings, and it can be assumed that the leaf colouring performs similar ecological functions as certain other types of variegation. Leaves with a non-green adaxial surface normally also have a non-green abaxial surface, but often of a different colour.

$\mathbf{V}$ Veins that are strikingly darker or lighter or of a different colour than the adjacent leaf surface (Figs. 4 \& 5). Not rarely, there is a marginal zone along such veins that is of the same colour, causing the veins to appear wider than they are (dilated veins, Fig. 4g). Often only the mid-vein or the main longitudinal veins stand out (Figs. 4a \& b), but sometimes secondary and tertiary veins are similarly coloured, producing a reticulate pattern (Figs. 4cg, 5b, d-f, h).

B Blotches and streaks that are delimited or guided by veins (Fig. 6). These are often angular or sigmoid in shape because veins tend to produce angular enclosures, or because the markings follow the course of an underlying cross-vein. Blotches can be small and isolated or large and adjacent, forming patches partitioned by veins (Fig. 6a). They often occur in rows (Fig. 6b). Sometimes, blotches consist entirely or partially of numerous tiny dots (Fig. 6c). In extreme cases, where the ground colour of the leaves is non-green and the veins are dilated, the leaf variegation can equally well be described as blotches delimited by veins or as dilated veins on a non-green background (Fig. 5h). Such cases have been coded as NV.

$\mathrm{S}$ Spots and dots that are independent of the veins (Figs. $7 \& 8$ ). Larger spots may extend across one or more veins and their distribution is often random, although they are sometimes arranged in a banding pattern (Fig. 11a), and then frequently a transverse one. Spots are often more rounded in shape than blotches that are delimited by veins, but they may also display unusual branching shapes (Fig. 11e). Large spots can be confluent, forming cloud-like patches (Fig. 7e), whereas small spots can form dense, granite-like patterns over the entire leaf surface (Fig. 8d \& e). Normally, spots are either much lighter or much darker than the surrounding leaf surface, although they can sometimes fade with age and eventually differ only slightly in colour from the rest of the leaf. In some Spiranthinae the spotting can be quite irregular and may form partial bands on some or all the leaves of the same plant (Fig. 8b).

L Longitudinal bands (Fig. 9). Bands may resemble dilated veins, but they are usually broader and more uneven in width and may cover several adjacent longitudinal veins; they often do not stretch along the entire length of an underlying vein. In Nervilia, which can have palmate venation, there may be a longitudinal band along each of the main veins, forming a star-like pattern.

If we assume that each of these five elements can occur separately or in any combination with others, then this simple system allows for 30 possibilities; 22 of these were observed among the orchids listed in the Appendix. Further refinements are easily implemented. For example, one could distinguish between light and dark markings (veins, blotches or spots); dilated and non-dilated, branching and non-branching veins; uniform spotting (with spots mostly in one size class) or heterogeneous spotting (spots much differing in size); fine dots versus larger spots, etc. This would raise the number of distinguishable patterns considerably, and when more data become available probably well over 60 general patterns could be recognized among the 


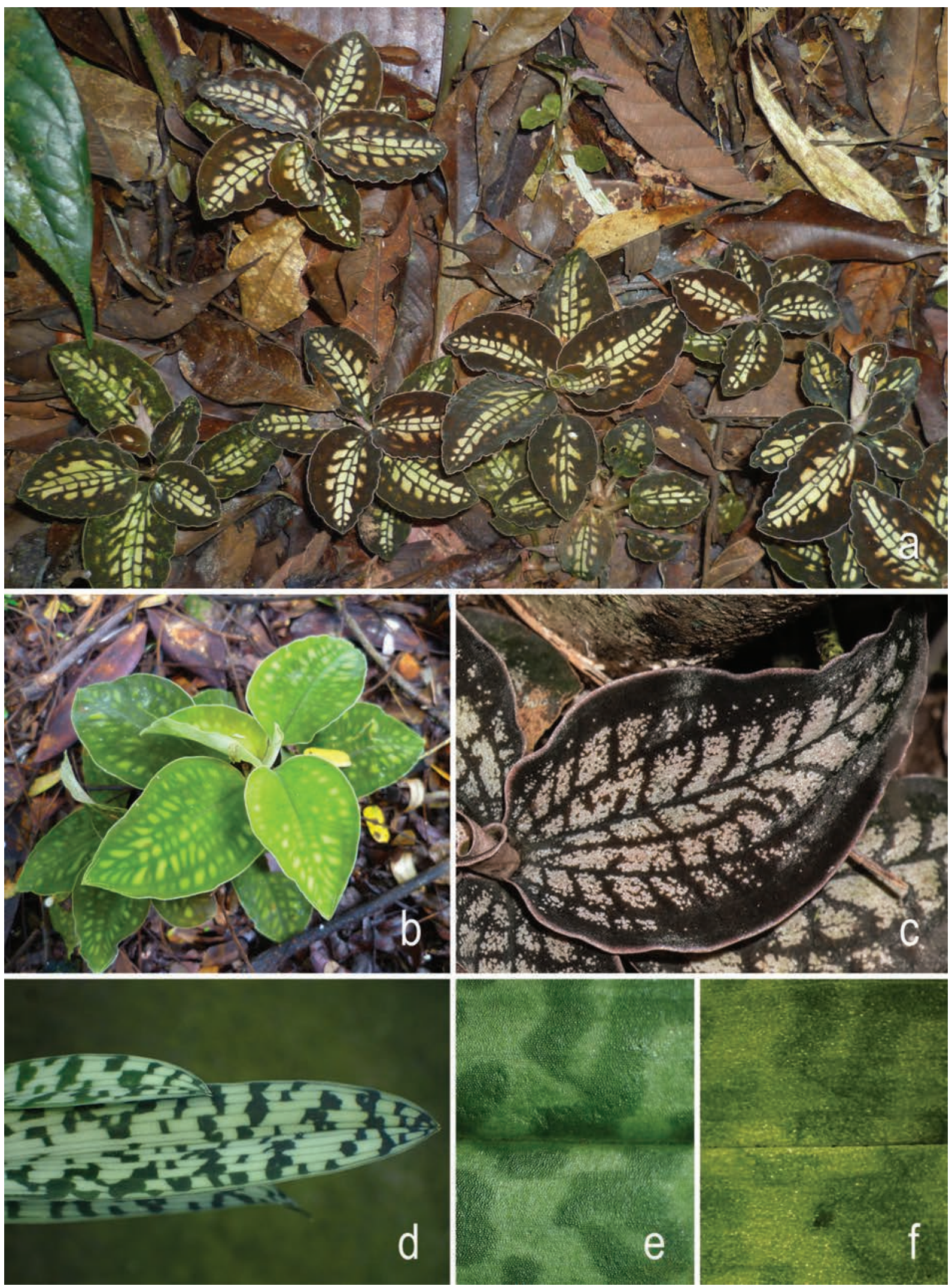

Fig. 6. Leaves with blotches delimited or guided by veins: a. Cystorchis sp. (in situ, Sabah); b. Cystorchis variegata var. variegata Blume (in situ, Malaysia); c. Eurycentrum obscurum (Blume) Schltr. (in situ, PNG); d. Paphiopedilum lawrenceanum (Rchb.f.) Pfitzer (cult.); e. Paphiopedilum venustum (Wall. ex Sims) Pfitzer (cult.), in reflected light; f. Paphiopedilum venustum (cult.), in transmitted light (photos a \& b by Peter O'Byrne, c by Fanie Venter, all others by André Schuiteman). 
orchids listed. To be useful, such a more refined system should not be carried to such an extreme that we can no longer recognize discrete character states.

\section{Results}

The most frequent type of variegation is the presence of distinctive veins (V), which occurs in $46 \%$ of the species in the Appendix. Close to 29\% have spotted leaves (S), about $27 \%$ have a non-green ground colour $(\mathrm{N})$, and nearly $16 \%$ have blotches delimited or guided by veins (B). A little more than 13\% have longitudinal bands (L). These percentages add up to more than $100 \%$, because different elements of variegation can be combined in the same leaf. Especially common are NV (89 species) and NS (27 species), but these cases are undoubtedly more common, as the leaf colour is often not recorded ("leaves mottled" is a common but too vague descriptor on specimen labels). Up to four elements can occur together in a single species in Nephelaphyllum Blume (BLNV) and Eulophia (BNSV).

Variegated species have been reported from three of the five subfamilies of Orchidaceae (Table 1), the exceptions being the two basal subfamilies Apostasioideae and Vanilloideae. The 800 species and 101 genera with variegated leaves are otherwise widely scattered throughout the family, but 72 genera have only 1-5 variegated species. Only nine genera have more than 20 variegated species: Gastrochilus D.Don (23 out of 68 species in total), Cyclopogon C.Presl (24/83), Lepanthes (28/1120), Anoectochilus (46/46), Corybas Salisb. (47/151), Crepidium Blume (48/260), Goodyera (49/98), Microchilus (50/251), and Paphiopedilum (52/86). The tribe Cranichideae is by far the richest in variegated orchids, with 320 species, while Orchideae, with 74 species, is second.

There is some phylogenetic signal in types of variegation. For example, spots (as defined above) are common and blotches are rare in Spiranthinae, whereas in the nearly related but more basal lineage Goodyerinae spots appear to be absent and blotches are fairly common. The fact that there is such a signal supports the biological reality of (part of) the scheme here adopted to classify variegation types.

Perhaps the most revealing statistic is that $79 \%$ of variegated species are terrestrial and only $22 \%$ are epiphytes (four are both terrestrial and epiphytic). On the other hand, about 75\% of all orchid species are epiphytic. A chi-square test for independence of variegation and life-form gives a $p$-value of $5 \times$ $10^{-271}\left(X^{2}=1,237\right.$; d.f. $\left.=1\right)$. It is, therefore, not surprising to find genera and higher clades with a predominance of terrestrial species being overrepresented in Table 1. Clades with few, if any, variegated species tend to comprise mainly epiphytic species. However, even some tribes and subtribes that almost exclusively contain terrestrial species, such as Diurideae (except Corybas), Neottieae, Sobralieae, Tropidieae, Chloraeinae, Pterostylidinae, and Disinae, harbour remarkably few variegated species. The same can be said of the genus Habenaria with 891 species, almost all terrestrial, only nine of which were here found to be variegated.

Variegated orchids are most diverse in tropical and subtropical Asia (close to $60 \%$ of the species included here) with the neotropics accounting for about half that percentage (Fig. 10), whereas they are poorly represented in Africa, Australia, extratropical America and Europe. However, some of the most striking instances of variegation are found in African and Madagascan Eulophia species (Fig. 11b-h).

\section{Discussion}

As already noted, a disproportionate $79 \%$ of variegated orchids are terrestrial, which strongly suggests that there is an ecological significance to variegation. This is even more plausible considering that an estimated $92 \%$ or more of variegated terrestrial orchids grow in the shade, usually in dense forest. It is also noteworthy that one of only four species of Bulbophyllum with variegated leaves, B. reticulatum (Fig. 5f), is one of the very few 
Table 1. Systematic distribution of variegated orchids, showing subfamilies, tribes and subtribes (where applicable), genus name, number of variegated species, percentage of variegated species within the genus, elements of variegation in the genus (B, L, N, S or V, see text).

\begin{tabular}{|c|c|c|}
\hline Cypripedioideae & Cryptostylis 4/17.39 (SV) & Epidendreae \\
\hline Cypripedium 6/11.76 (S) & Orchideae & Laeliinae \\
\hline Paphiopedilum 52/60.47 (BV) & Brownleeinae & Domingoa 2/50 (S) \\
\hline Orchidoideae & Disperis 16/20.51 (NSV) & Epidendrum 2/0.12 (S) \\
\hline Cranichideae & Disinae & Homalopetalum 1/11.11 (S) \\
\hline Cranichidinae & Disa $4 / 2.2(\mathrm{~S})$ & Scaphyglottis 1/1.28 (S) \\
\hline Cranichis 5/6.85 (BLNV) & Orchidinae & Pleurothallidinae \\
\hline Ponthieva $1 / 1.52(\mathrm{~L})$ & Cynorkis 14/8.97 (BNSV) & Acianthera 8/2.75 (S) \\
\hline Prescottia 1/3.85 (L) & Dactylorhiza 5/38.46 (S) & Anathallis 4/3.39 (S) \\
\hline Goodyerinae & Dracomonticola 1/100 (V) & Andinia 20/27.03 (V) \\
\hline Aenhenrya 1/100 (BL) & Galearis 1/10 (S) & Dryadella 2/3.51 (S) \\
\hline Anoectochilus 46/100 (NV) & Habenaria 9/1.01 (BLNSV) & Gravendeelia 1/100 (V) \\
\hline Bidoupia 2/100 (NV) & Hemipilia 9/69.23 (LSV) & Lepanthes 28/2.5 (NV) \\
\hline Cheirostylis 15/26.79 (LNV) & Holothrix 1/2.22(V) & Pabstiella 2/1.43 (S) \\
\hline Cystorchis 14/70 (BNV) & Neotinea $1 / 25(\mathrm{~S})$ & Specklinia 2/2 (S) \\
\hline Dossinia $1 / 100(\mathrm{~V})$ & Orchis $4 / 19.05(\mathrm{~S})$ & Stelis $1 / 0.1(\mathrm{~S})$ \\
\hline Eurycentrum 2/100 (BNV) & Platanthera 1/0.71 (V) & Teagueia 1/7.14 (V) \\
\hline Gonatostylis 1/50 (BNV) & Ponerorchis 2/4.08 (S) & Trisetella 2/7.69 (S) \\
\hline Goodyera 49/50 (BLNV) & Sirindhornia 3/100 (S) & Malaxideae \\
\hline Kuhlhasseltia 4/80 (N) & Stenoglottis 3/60 (S) & Malaxidinae \\
\hline Ludisia 1/100 (NV) & Epidendroideae & Crepidium 48/18.46 (LNSV) \\
\hline Macodes 11/100 (LNV) & Arethuseae & Liparis 3/0.70 (LNV) \\
\hline Microchilus 50/19.92 (BLNV) & $\begin{array}{l}\text { Arethuseae } \\
\text { Coelogyninae }\end{array}$ & Oberonia 1/0.36 (S) \\
\hline Odontochilus 8/14.29 (NV) & $\begin{array}{l}\text { Coelogyninae } \\
\text { Coelogyne 4/0.69 (N) }\end{array}$ & Dendrobiinae \\
\hline Pachyplectron 2/66.67 (BN) & $\begin{array}{l}\text { Coelogyne } 4 / 0.09(\mathrm{~N}) \\
\text { Calypsoeae }\end{array}$ & Bulbophyllum 4/0.21 (V) \\
\hline Papuaea $1 / 100(\mathrm{~V})$ & $\begin{array}{l}\text { Calypsoeae } \\
\text { Cremastra 1/50 (S) }\end{array}$ & Nervilieae \\
\hline Rhomboda 17/70.83 (NV) & Ephippianthus 1/100 (V) & Nerviliinae \\
\hline Vrydagzynea 14/33.33 (LNV) & Tipularia 2/28.57 (S) & Nervilia 16/20.51 (BLNSV) \\
\hline Zeuxine 13/16.25 (LNV) & Collabieae & Podochileae \\
\hline Manniellinae & Calanthe 4/1.53 (LS) & Porpax 1/2.38 (BV) \\
\hline Manniella 1/50 (B) & Collabium 12/80 (LS) & Triphoreae \\
\hline Spiranthinae & Diglyphosa 1/100 (S) & Triphorinae \\
\hline Coccineorchis 1/14.29 (LS) & Nephelaphyllum 11/84.61 (BLNV) & Monophyllorchis 1/100 (V) \\
\hline Cyclopogon 24/28.92 (LNS) & Plocoglottis 3/8.33 (NLS) & Vandeae \\
\hline Mesadenella 3/42.86(LS) & Tainia 3/10.34 (NS) & Aeridinae \\
\hline Mesadenus 1/25 (V) & Cymbidieae & Gastrochilus 23/33.82 (S) \\
\hline Pelexia 12/13.33 (BLNS) & Eulophiinae & Papillilabium 1/100 (S) \\
\hline Pseudogoodyera $1 / 100(\mathrm{~V})$ & Eulophia 18/7.2 (BNSV) & Phalaenopsis 6/8 (NS) \\
\hline Pteroglossa 2/15.38 (S) & Maxillariinae & Rhynchostylis 3/75 (V) \\
\hline Sacoila 1/12.5 (V) & Maxillaria 2/0.35 (S) & Robiquetia 2/2.2 (S) \\
\hline Sarcoglottis 13/25 (LNS) & Oncidiinae & Saccolabiopsis $1 / 7.14(\mathrm{~S})$ \\
\hline Stenorrhynchos 4/80 (LS) & Macroclinium 11/22.45 (S) & Sarcochilus $4 / 21.05(\mathrm{~S})$ \\
\hline Diurideae & Psychopsiella 1/100 (NS) & Schistotylus 1/100 (S) \\
\hline Acianthinae & Psychopsis 4/100 (NS) & Angraecinae \\
\hline Corybas 47/31.33 (NV) & Quekettia 5/71.43 (BS) & Aerangis 1/1.72 (S) \\
\hline Cryptostylidinae & Trichocentrum 17/21.52 (S) & Angraecum 1/0.45 (S) \\
\hline
\end{tabular}


terrestrial species in this genus of $c .2000$ species (Vermeulen et al., 2017).

It is well known that plants with variegated leaves predominantly inhabit the forest floor and it has been suggested that variegation is an adaptation to low light levels, which somehow enables the plant to absorb the light more efficiently. There is little evidence for this (Esteban et al., 2008; La Rocca et al., 2011, 2014; Hughes et al., 2019). Another physiological explanation is that variegation would enable a plant growing in deep shade to avoid damage by occasional sunspots. Published evidence that such damage is a significant risk to shade plants (sciophytes) or that variegation would mitigate against it could not be found.

Different types of variegation may represent different adaptive strategies. There is some evidence that variegated plants are less frequently damaged by herbivores or attacked by pests than if they were plain green (Campitelli et al., 2008; Soltau et al., 2009). The most common function of variegation is likely to be herbivore avoidance, and this probably explains why orchids that grow on the forest floor are more often variegated than those that grow in the open or on trees. The sparse vegetation in a shady forest, with plants growing in isolation, makes the latter more conspicuous and more vulnerable to herbivores. Under these circumstances, variegation might become a valuable defence mechanism. Variegated plants (not orchids) are also relatively common in semi-desert vegetation, which could hardly be a more different environment. The common factor here is obviously not light level or humidity, it is the scattered occurrence of the plants and the way they potentially stand out to predators. If there is strength in numbers, there is vulnerability in isolation.

Given that relatively few epiphytic orchids are variegated (22\% of variegated species) it can be inferred that terrestrial (i.e., non-arboricole) mammals are the main class of herbivore against which protection is sought. We may call variegation that aims to defend against herbivores "defensive colouration" (Lev-Yadun, 2016). Such defensive colouration can take three forms: camouflage, mimicry, or aposematic colouration. In the case of mimicry, the function of variegation can also be non-defensive and some possible examples are discussed below.

\section{Camouflage}

Camouflage is the art of not being seen in plain sight. Since plants on the forest floor tend to stand out if they look like an ordinary green plant, there is an advantage to being less conspicuous. This is especially so for small and delicate, slow-growing herbs like most orchids, which are unlikely to survive the attention of a browsing herbivore (Hughes et al., 2019). Visual camouflage is, on the other hand, not a useful defence strategy against such enemies as slugs and snails, which again suggests that this kind of defensive colouring is mainly adapted to herbivory by mammals (protection against insects and birds is probably a lesser factor, otherwise one would expect more epiphytes to show defensive colouring; however, this does not take into account the possibility of patterns only visible in infrared or UV light). It must be remembered that the eyes of herbivores may see fewer or different colours than those of the average human, and their resolving power may also be lower, which could make it slightly easier for a plant to escape the attention of a predator by adopting defensive colouration, especially under conditions of low light intensity. The human eye may find some examples not particularly cryptic, moreover, disruptive colouration (Cuthill et al., 2005) may make a variegated leaf appear conspicuous from nearby while turning it into a confusing medley of spots and streaks from afar (Fig. 6a \& c).

Since plants cannot directly adapt their leaf markings to their surroundings, a camouflaged plant in the forest will in general resemble "an average piece of forest floor", which is a chaotic tapestry of leaf litter, fallen twigs, pieces of bark and lichen, mosses, etc. This means that such cryptic leaves are often dark or brown coloured, if they 

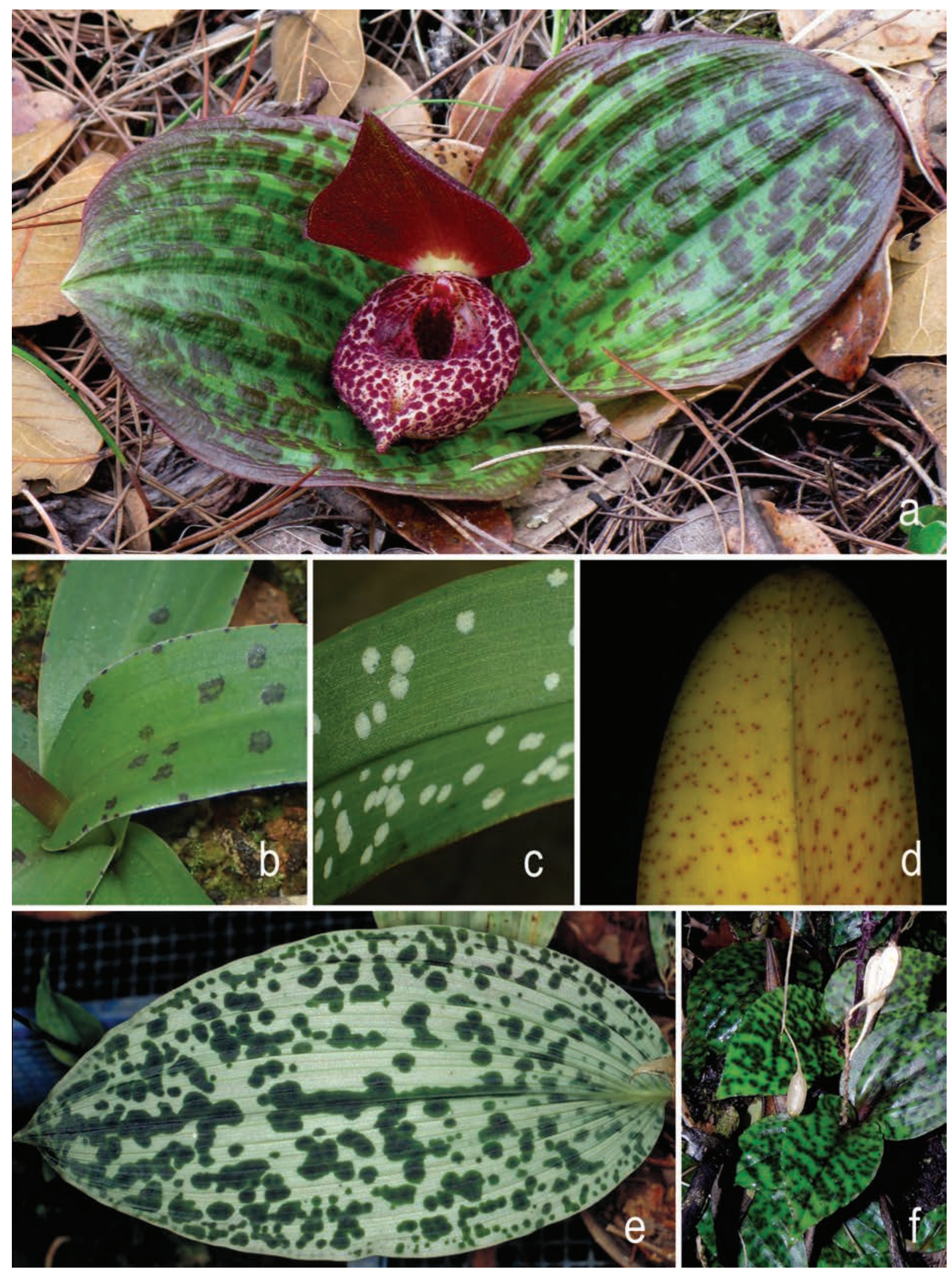

Fig. 7. Leaves with free spots: a. Cypripedium lichiangense S.C.Chen \& P.J.Cribb (in situ, China); b. Cynorkis purpurea (Thouars) Kraenzl. (cult.); c. Maxillaria pseudoreichenheimiana Dodson (cult.); d. Trichocentrum carthagenense (Jacq.) M.W.Chase \& N.H.Williams (cult.); e. Collabium simplex Rchb.f. (cult.); f. Crepidium maculatum (Ridl.) Schuit. \& J.J.Wood (in situ, Sabah) (photo a by Phillip Cribb, b \& c by André Schuiteman, d by Henry Oakeley, e \& f by Peter O'Byrne). 

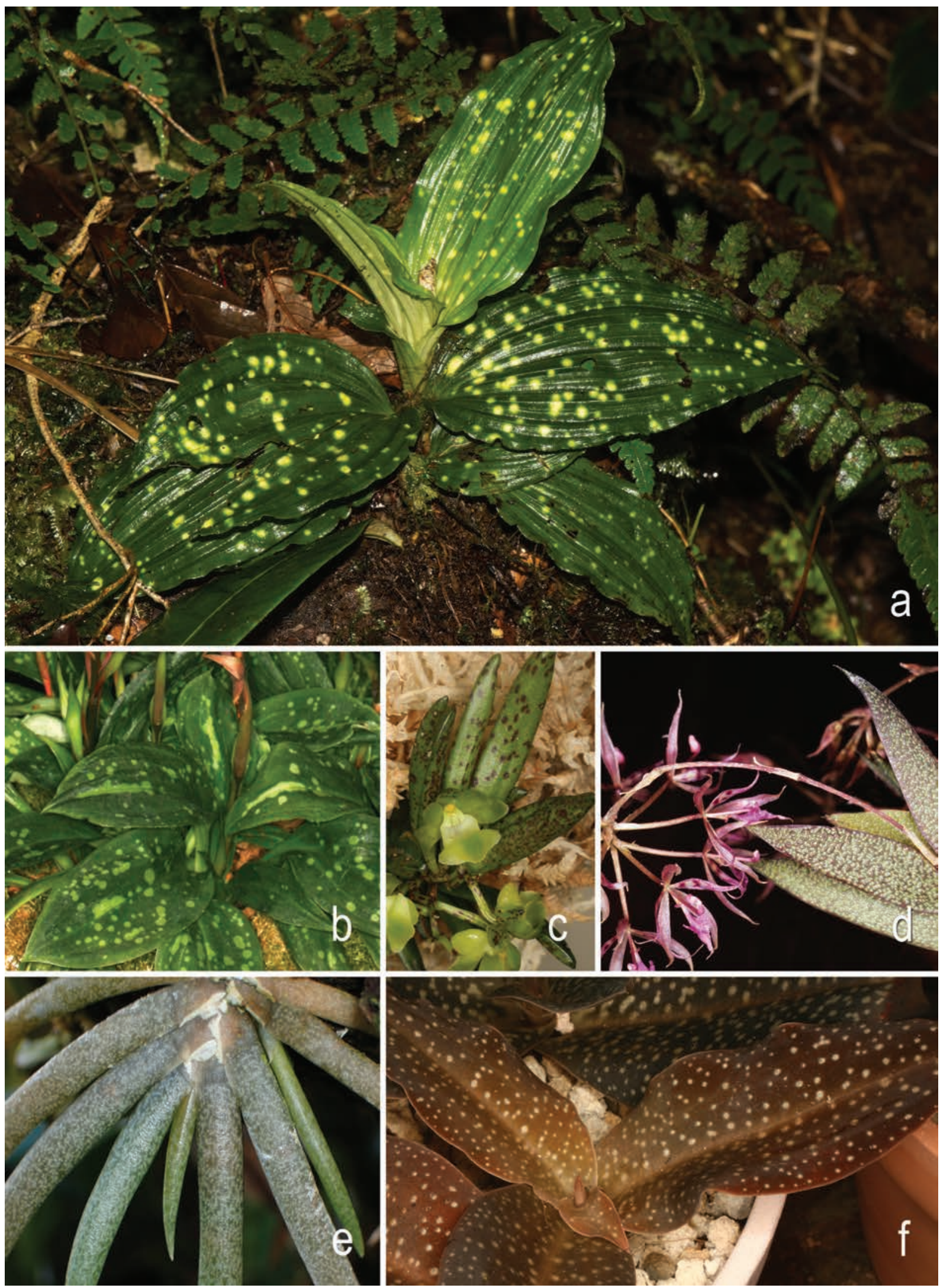

Fig. 8. Leaves with free spots: a. Calanthe sp. (in situ, Papua New Guinea); b. Stenorrhynchos speciosum (Jacq.) Rich. (cult.); c. Gastrochilus matsuran (Makino) Schltr. (cult.); d. Macroclinium cf. dalstroemii Dodson (cult.); e. Oberonia cavaleriei Finet (cult.); f. Habenaria carnea Weathers (cult.) (photo a by Fanie Venter, b, c \& f by Henry Oakeley, d by Stig Dalström, e by André Schuiteman). 

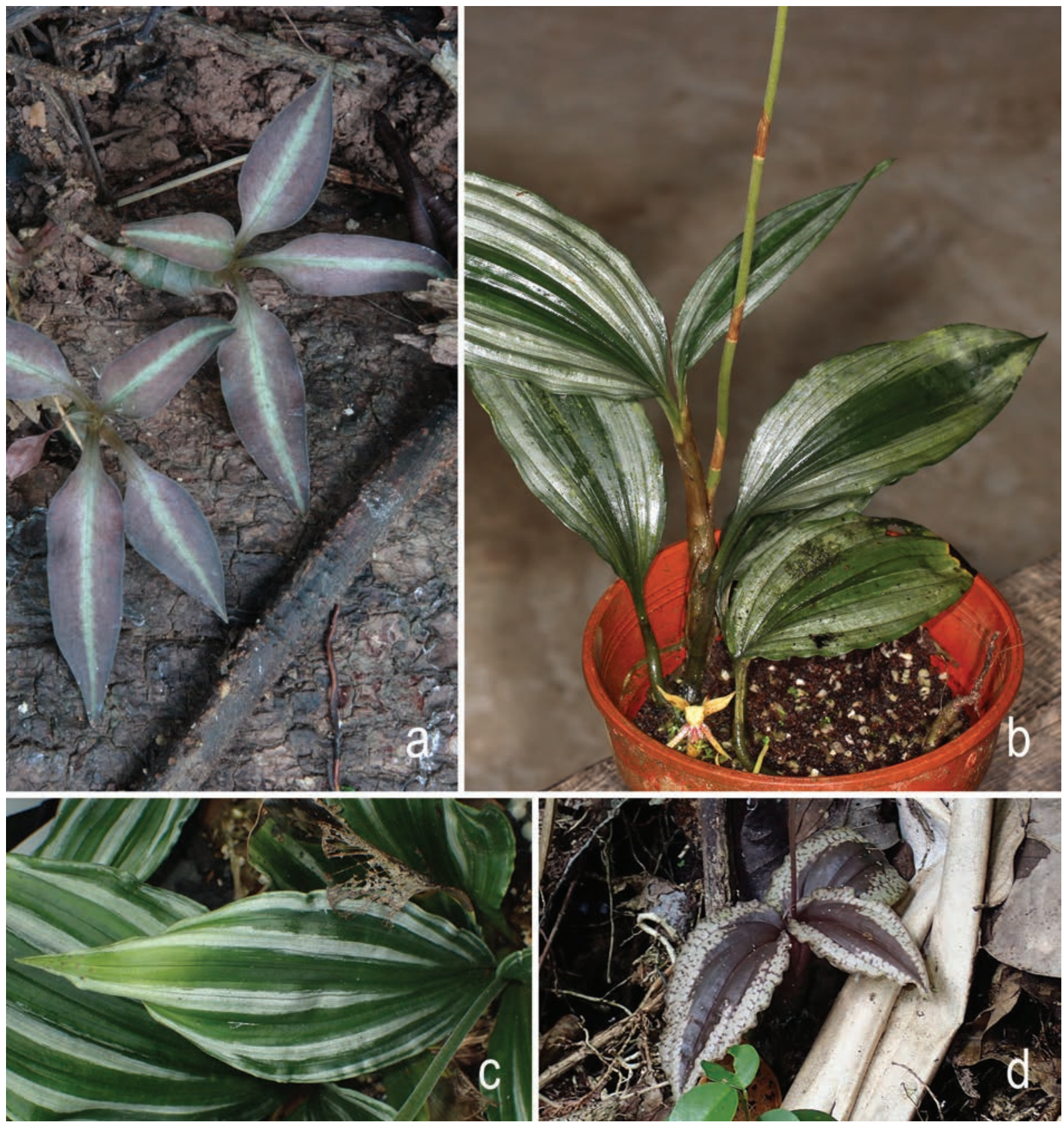

Fig. 9. Leaves with longitudinal bands: a. Cheirostylis sp. (in situ, Laos); b. Plocoglottis plicata (Roxb.) Ormerod (cult.); c. Calanthe argenteostriata C.Z.Tang \& S.J.Cheng (cult.); d. Crepidium calophyllum (Rchb.f.) Szlach. (in situ, Malaysia) (photos a \& c André Schuiteman, b \& d by Peter 0’Byrne).

are not otherwise marked, or they will present an irregular pattern of spots, lines and blotches that tends to blur the outline of the leaf. In addition, the leaves will often be held close to the ground (strikingly so in Nervilia plicata (Andrews) Schltr., Fig. 12b). Camouflaged leaves may even be relatively colourful up close (disruptive colouration), but their pattern may make them difficult to place in visual space. In Figs. 11 \& 12 some examples of putative camouflaged orchids are shown. When examining these photographs, one must keep in mind that flash photography tends to make the subject stand out far more than under natural light conditions. Indeed, it may be so dark on the forest floor that it is hardly possible to take good photographs without artificial light. Not all examples of supposed camouflage are of plants growing on the forest floor; several species of 


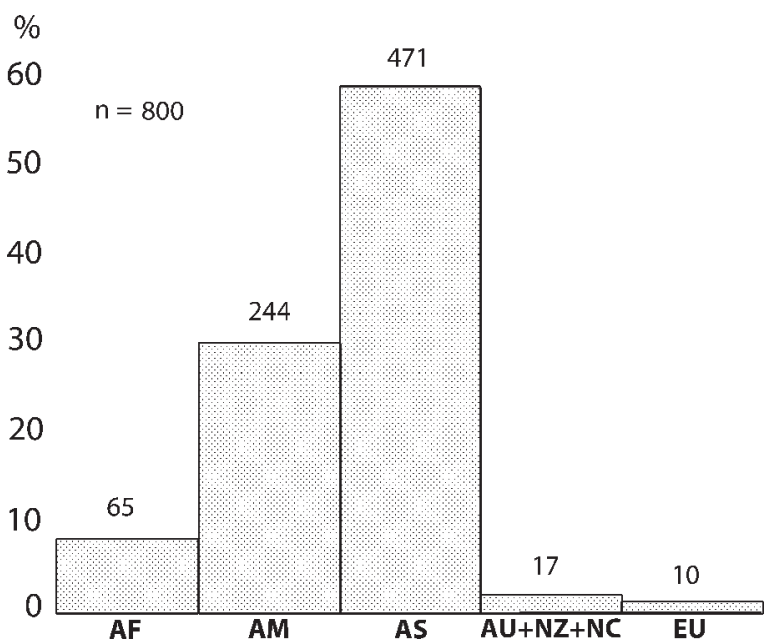

Fig. 10. Occurrence of variegated orchids by continent $(A F=$ Africa and Madagascar, $\mathrm{AM}=$ America, $\mathrm{AS}=\mathrm{Asia}, \mathrm{AU}+\mathrm{NZ}+\mathrm{C}=$ Australia, New Zealand and New Caledonia, EU = Europe). Please note that a few species occur in more than one continent, hence the numbers in the columns add up to more than 800 .

Paphiopedilum grow on semi-shaded limestone cliffs (Fig. 12f) and their irregularly tessellated leaves may make them harder to spot against the background of rough, lichen-flecked rock surfaces. It is perhaps worth pointing out that not all camouflaged plants will happen to grow in a spot that makes their camouflage effective; camouflage only needs to increase fitness at the population level.

Two of the species among the putatively camouflaged ones illustrated here are epiphytes: Phalaenopsis celebensis H.R.Sweet (Fig. 11a) and Psychopsiella limminghei (E. Morren ex Lindl.) Lückel \& Braem (Fig. 12e). The latter has a peculiar habit of growing flat appressed against a tree trunk, and it is easy to imagine this irregularly spotted plant being cryptic against a moss-and-lichen-covered surface. The hanging leaves of Phalaenopsis celebensis also have a colouring suggestive of a lichen-covered tree trunk. Both could also be said to display disruptive colouring, but camouflage by imitating the background seems more plausible here.

\section{Mimicry}

If camouflage is the art of not being seen, then mimicry is the art of being seen for something else. The distinction between camouflage and mimicry is not always clear cut. Is Habenaria rhodocheila Hance (Fig. 13b) camouflaged because its brownish leaves are not easy to spot among leaf litter, or is it mimicking a dead leaf, complete with fungal spots, and hence appearing unpalatable? Is Eulophia decaryana H.Perrier (Fig. 11c \& h) safely camouflaged in its Madagascan dry forest because of its cryptic colour and irregular spotting or is it mimicking a dead twig? One would almost have to be able to question an actual herbivore. Would the answer be: "I saw it, but I don't like to eat dead leaves and dry twigs," or would it be, "I didn't see it"?

One of the main problems of demonstrating mimicry is to determine the target organism. This is relatively easy in the case of flowers mimicking something of interest to pollinators because one can just wait for the pollinator to visit the flower. But in the case of defensive mimicry the effect should be avoidance of visits, a lack of interaction. It is likely that many kinds of leaf spotting in variegated orchids resemble fungal or bacterial infections, and these would presumably deter certain herbivores (compare, for example, Fig. 14b with 2e, or $8 \mathrm{~b}$ with $2 \mathrm{f})$. On the other hand, spots like in Fig. $8 \mathrm{~b}$ also resemble epiphyllous lichens or even leaf mines. As a perusal of the figures in this paper will demonstrate, there is a great variety of leaf markings in orchids, and it can be difficult to establish what they are supposed to imitate, and whether they are defensive or not. Nevertheless, it seems plausible that leaf variegation of the kind we see in these photographs is either camouflage or a kind of mimicry. The occurrence of a third possibility, aposematic colouration, with coloured patches warning for the presence of tissue rich in, e.g., raphids (Lev-Yadun, 2016) or poisonous substances, or with the orchid mimicking the warning colours of a poisonous organism (possibly another plant species with similar markings), has not yet been demonstrated. The latter would be a case of Batesian mimicry (Lev-Yadun, 2016). Examples of aposematic colouring could include certain conspicuously veined or banded orchids, such as Vrydagzynea tristriata Ridl. (Fig. 4b), Cheirostylis 


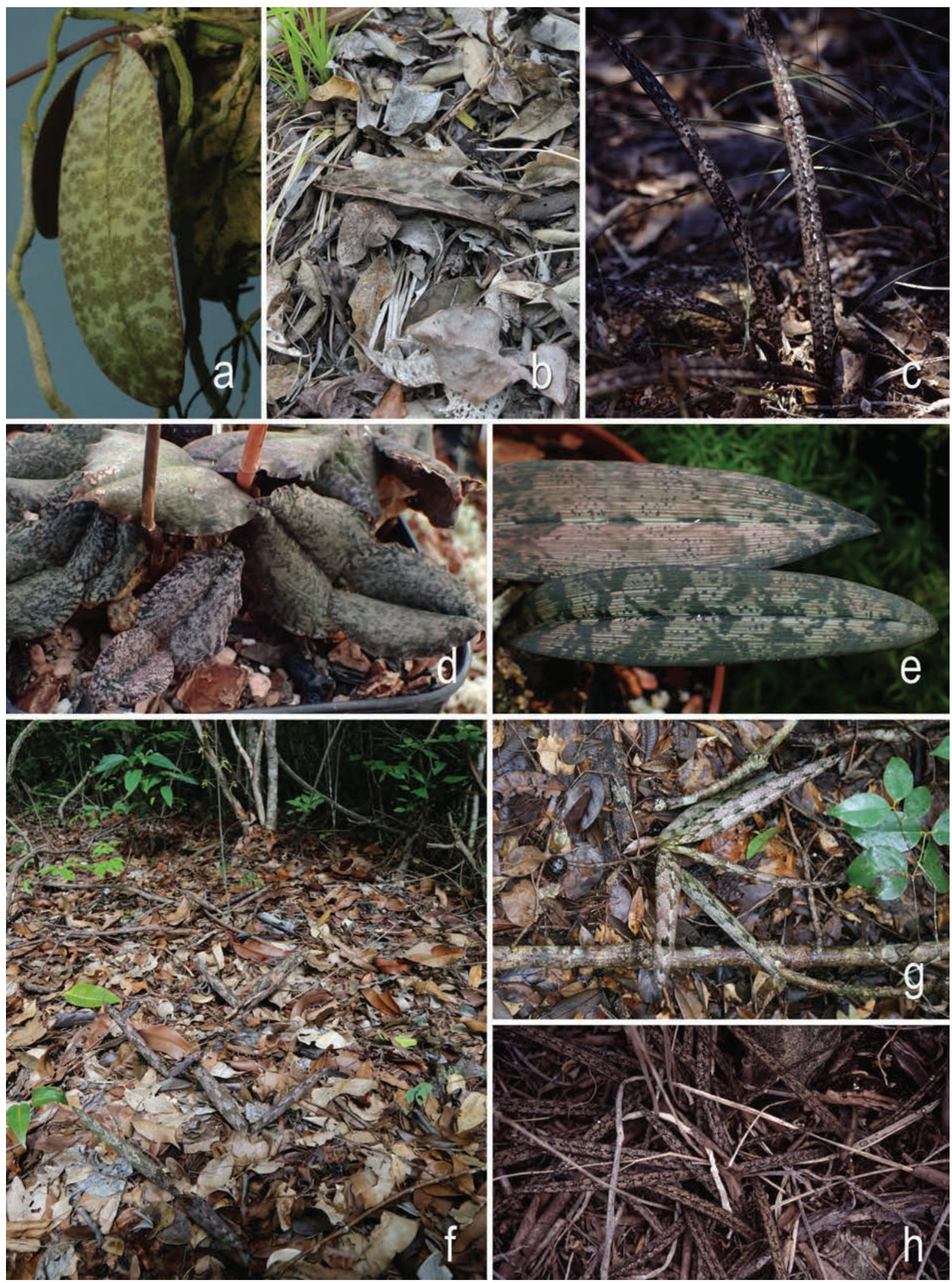

Fig. 11. Leaves with putative camouflage patterning: a. Phalaenopsis celebensis H.R.Sweet (cult.); b. Eulophia maculata (Lindl.) Rchb.f. (in situ, Madagascar); c. Eulophia decaryana H.Perrier (in situ, Madagascar); d. Eulophia roseovariegata (Senghas) M.W.Chase \& Schuit. (cult.); e. Eulophia spathulifera H.Perrier (cult.); f. Eulophia spathulifera (in situ, Madagascar); g. Eulophia spathulifera (in situ, Madagascar); h. Eulophia decaryana (in situ, Madagascar) (photos a, d \& e by André Schuiteman, b, c, f-h by Johan Hermans). 

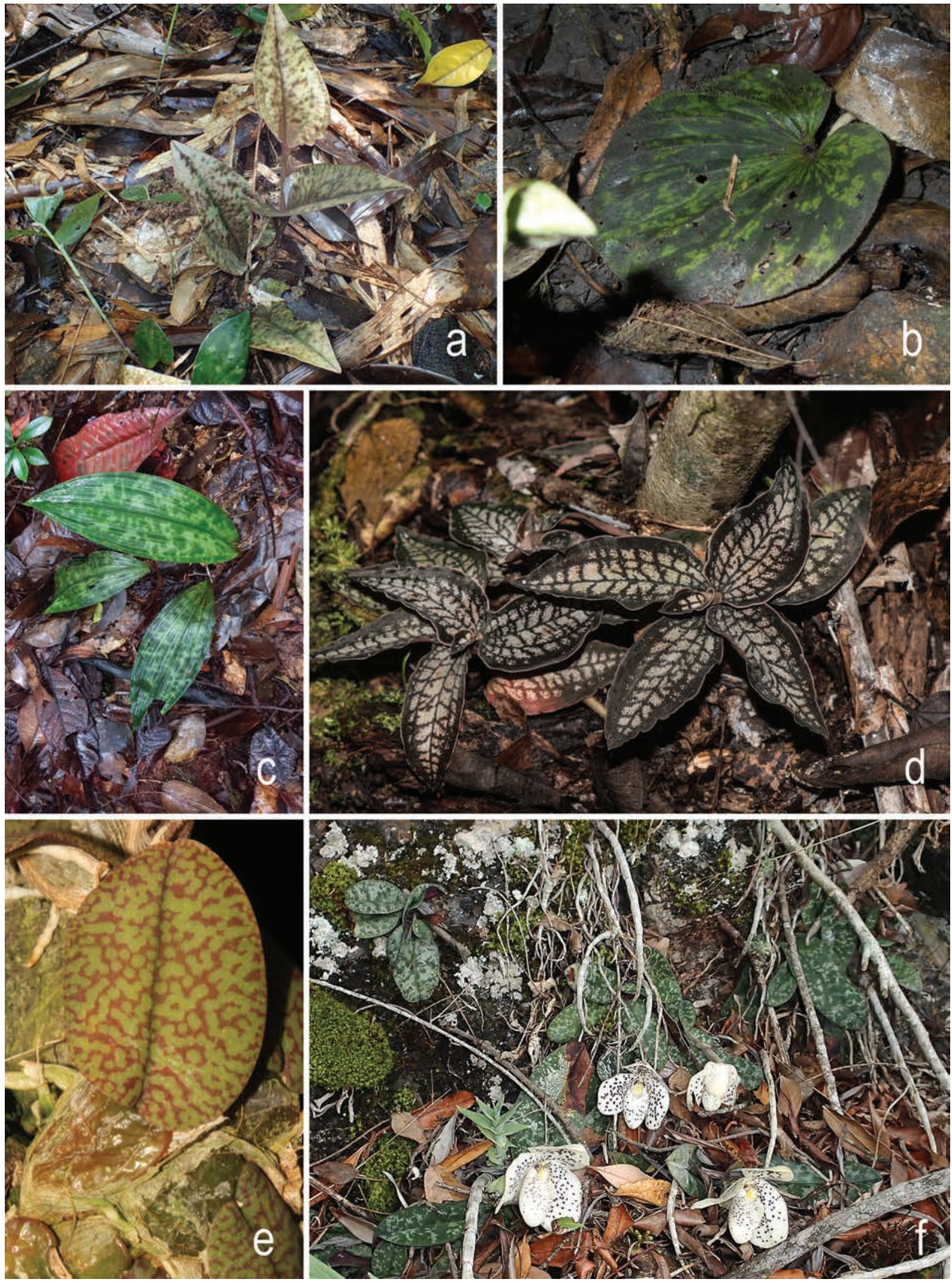

Fig. 12. Leaves with putative camouflage patterning: a. Nephelaphyllum pulchrum Blume (in situ, Cambodia); b. Nervilia plicata (Andrews) Schltr. (in situ, Cambodia); c. Collabium aff. simplex Rchb.f. (in situ, West Papua Prov., Indonesia); d. Eurycentrum obscurum (Blume) Schltr. (in situ, PNG); e. Psychopsiella limminghei (É Morren ex Lindl.) Lückel \& Braem (cult.); f. Paphiopedilum wenshanense Z.J.Liu \& J.Yong Zhang (in situ, China) (photo d by Fanie Venter, e by Rudolf Jenny, $f$ by Peter O’Byrne, all others by André Schuiteman). 

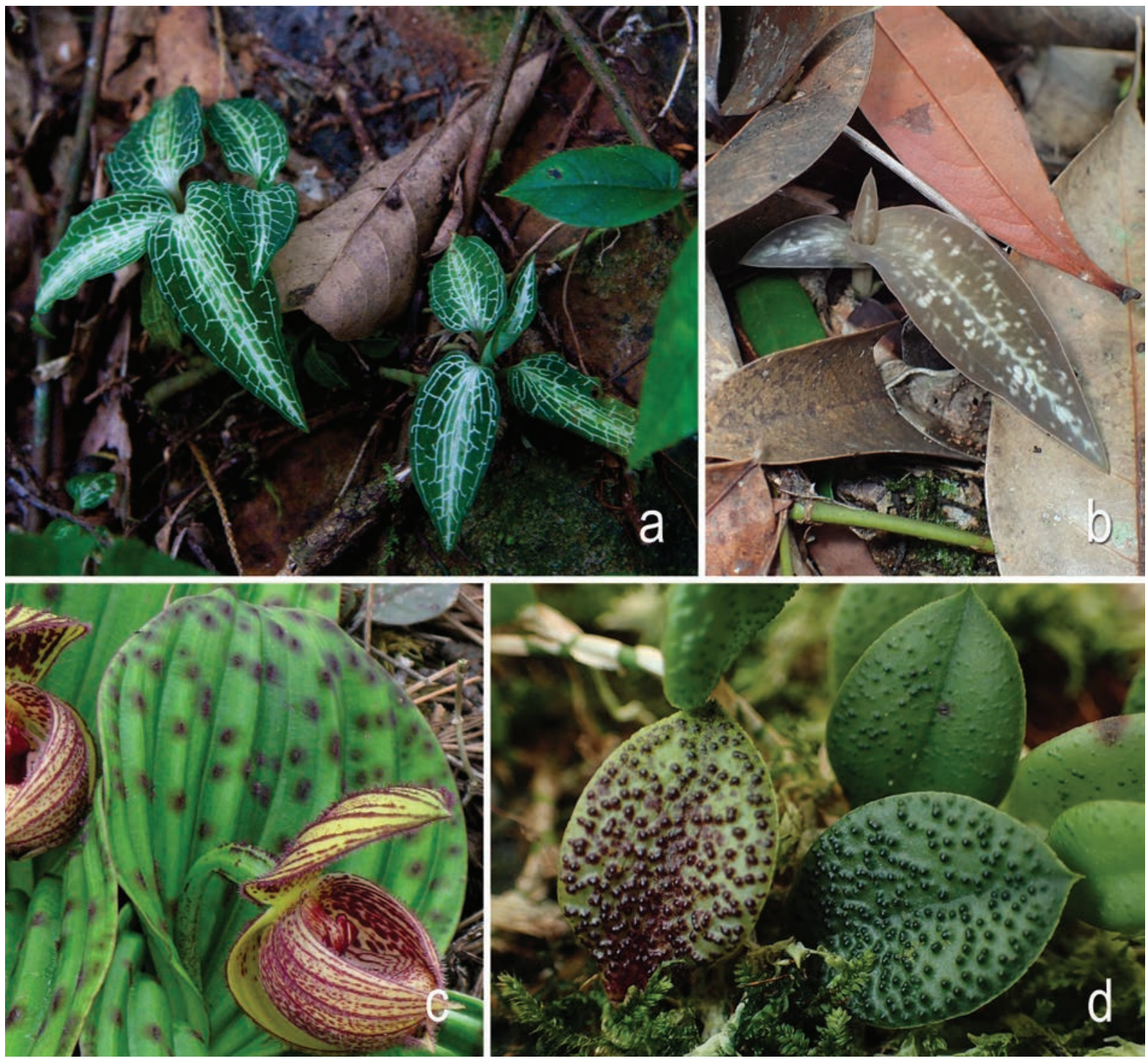

Fig. 13. Leaves displaying putative mimicry: a. Goodyera reticulata (Blume) Blume (in situ, Java); b. Habenaria rhodocheila Hance (in situ, Cambodia); c. Cypripedium margaritaceum Franch. (in situ, China); d. Acianthera dodsonii (Luer) Karremans \& Rinc.-González (cult.) (photo c by Phillip Cribb, all others by André Schuiteman).

sp. (Fig. 9a), or Calanthe argenteostriata C.Z.Tang \& S.J.Cheng (Fig. 9c), but in the last two examples the banding may also serve to create the illusion of the leaves being much narrower than they really are, thereby making them of less interest as a food source.

Non-defensive mimicry is probably less common than defensive mimicry. An example would be Cypripedium fargesii Franch., which not only has brown-spotted leaves, but the spots also have a central raised and darker centre that somewhat resembles fungal conidia, to which the pollinators of this species, syrphid flies of the genus Cheilosia Meigen, may be attracted (Ren et al., 2011, 2012). The closely related C. margaritaceum Franch. (Fig. 13c) has the same kind of spots (a dark raised centre with a paler brown halo), but another nearly related species, C. lichiangense S.C.Chen \& P.J.Cribb (Fig. 7a) seems to lack the raised centre in the more uniform-looking spots. It is possible that spotting in the ancestral species originally evolved as defensive mimicry (making the leaves look fungus-infected) and then secondarily developed traits that made them attractive to pollinators. The mimicry in this case may be both 

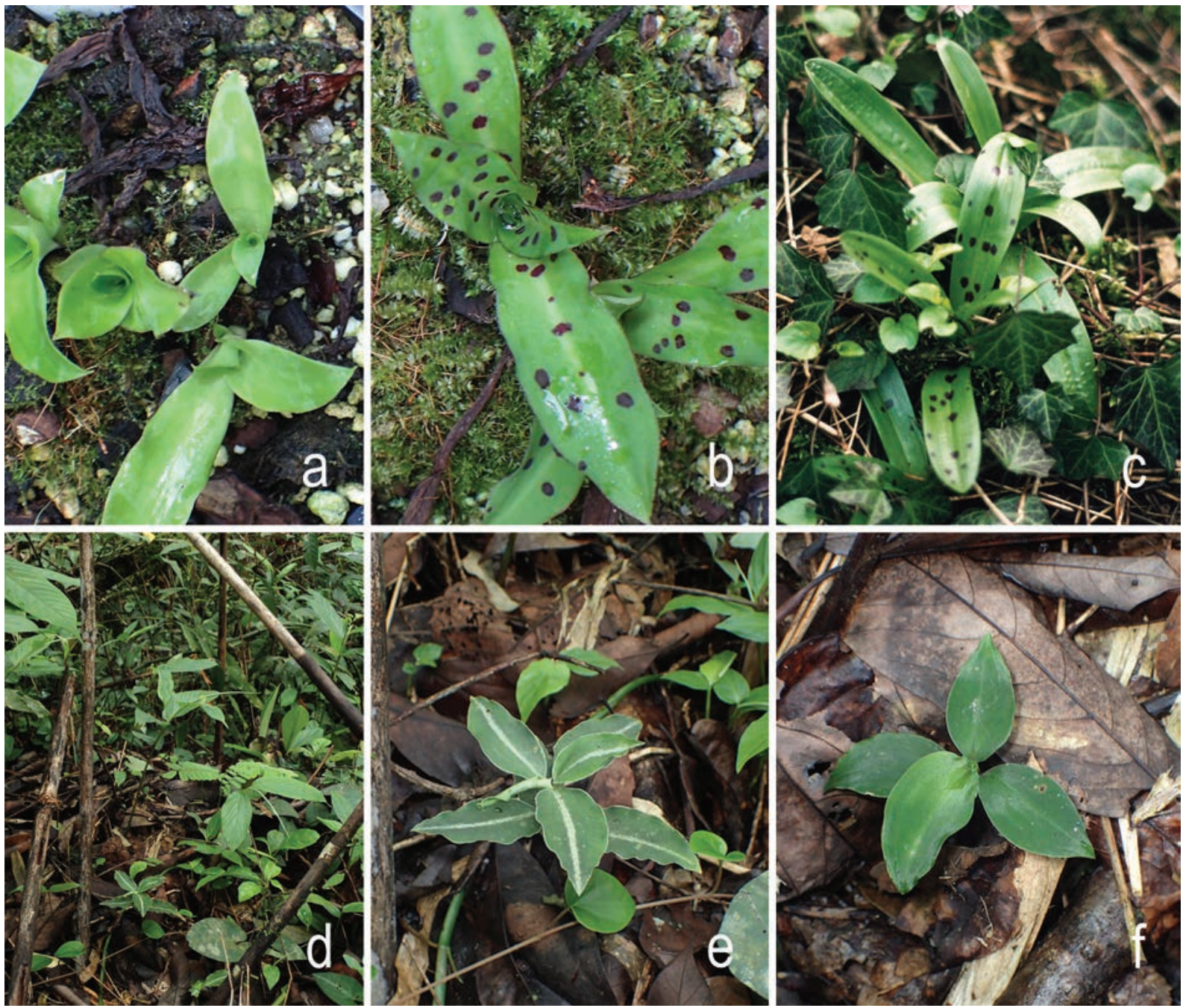

Fig. 14. Leaves displaying putative mimicry: a. Stenoglottis longifolia Hook.f. (cult.), unspotted clones; b. Stenoglottis longifolia (cult.), spotted clones; c. Orchis mascula (L.) L. (in situ, Netherlands), spotted and unspotted plants growing next to each other; d. Vrydagzynea albida (Blume) Blume (in situ, Cambodia; note similarly marked non-orchid leaf in bottom right hand corner); e. Vrydagzynea albida (in situ, Cambodia), with white midvein; f. Vrydagzynea albida (same locality as d \& e), with plain green leaves (photos by Andrá Schuiteman).

defensive and non-defensive, depending on the target organism.

The remarkable, raised, blackish and glossy warts on the leaf of Acianthera dodsonii (Luer) Karremans \& Rinc.-González (Fig. 13d) resemble an aphid colony, and may attract pollinators that feed on aphids. It has been established (Pemberton, 2013) that several species of Paphiopedilum attract syrphid flies as pollinators by presenting aphid-like structures in the flowers (the larvae of some syrphid flies feed on aphids). Therefore, it is not implausible that $A$. dodsonii practices a similar kind of deception to attract pollinators, the more so as in this species the flowers lie directly on the adaxial leaf surface.
Lev-Yadun (2016) gave various examples of aphid mimicry in other plant groups.

Regarding the striking, glistening, reticulated veins seen in many species of Anoectochilus (Fig. 1), Goodyera (Figs. 4d, 13a), Macodes Lindl. (Fig. 4e), etc., it seems implausible that these make the plants harder to spot, and it may be hypothesized that they mimic a spider's web. This would presumably deter insects as well as mammals. An alternative explanation could be that these conspicuous veins produce a dazzle effect (Lev-Yadun, 2014) to confuse herbivores, or they may represent aposematic colouration. 
There are several (and probably many) cases of variegated orchids where individuals with plain green leaves occur alongside those of the same species with variegated leaves (Fig. 14). This dimorphism is especially common in species with dark spotting and occurs among unrelated species. Examples include Cynorkis purpurea (Thouars) Kraenzl. (Madagascar), Cypripedium forrestii P.J.Cribb (China), Disa fragrans Schltr. (South Africa), Galearis roborovskii (Maxim.) S.C.Chen, P.J.Cribb \& S.W.Gale (Himalaya and China), Orchis mascula (L.) L. (Europe), Ponerorchis cucullata (L.) X.H.Jin, Schuit. \& W.T.Jin (China, not in European populations), Stenoglottis longifolia Hook.f. (Southeast Africa), and Tipularia discolor (Pursh) Nutt. (North America; Hughes et al., 2019). A possible explanation for this phenomenon is that the spotting is a defensive mimicry that would be less effective if too many individuals displayed the syndrome. There could then be negative frequency-dependent selection (Gigord et al., 2001, but see also Groiß et al., 2017) against spotted leaves: if the number of individuals in a population with spotted leaves is below a certain threshold, then protection from mimicry would increase their fitness compared to plain green individuals, but if too many have spotted leaves, predators may quickly learn that they are just as edible as plain green ones and the advantage in fitness would disappear. It would be interesting to monitor such a mixed population over time and to establish the genetic basis for the spotting polymorphism. In several species with other types of variegation individuals with plain green leaves have also been observed. Some examples are: Aspidogyne querceticola (Lindl.) Meneguzzo (white blotches may be absent), Calanthe woodfordii (Hook.) M.W.Chase, Christenh. \& Schuit. (yellowish spots may be absent), Corybas subalpinus P.Royen (silvery reticulated veins may be absent), Crepidium purpureum (Lindl.) Szlach. (leaves metallic redpurple but may be plain green), Nervilia concolor (Blume) Schltr. (large dark green blotches arranged in a semicircle often absent), Paphiopedilum niveum (Rchb.f.) Stein (sometimes not tessellated),
Plocoglottis plicata (Roxb.) Ormerod (silvery bands may be absent; Fig. 9b); Vrydagzynea albida (Blume) Blume (white mid-vein may be absent; Fig. 14df). These examples show that most types of variegation can be suppressed in individual plants, although there is no evidence that the same individual can be variegated or not at different times; it appears to be genetically fixed one way or the other. The co-occurrence of variegated and plain green individuals of the same species has also been observed in other plant families, e.g., in Araceae (Soltau, 2009) and Begoniaceae (Sheue et al., 2021).

That many variegated orchid species may have non-variegated morphs growing in the same habitat is additional evidence that there is no physiological advantage to these types of variegation. At the same time, the occurrence of similar patterns of variegation in distantly related and geographically isolated taxa does suggest that they increase fitness under certain conditions. Controlled experiments under field conditions are needed to test this hypothesis.

\section{Conclusions}

Leaf variegation is a widespread phenomenon in Orchidaceae, both systematically and geographically, with at least 800 variegated species in 101 genera being known so far. Although only two anatomical features underlie most cases (presence of non-green pigments and intercellular spaces in the subcuticular tissue), there are scores of distinguishable types of variegation in orchids. A simple scheme of five basic elements is here proposed; based on this scheme 22 general variegation patterns have been observed. If the variability in the five basic elements is taken into account, for example by distinguishing between light and dark spots, the number of general variegation patterns may well exceed 60 .

Almost $80 \%$ of variegated orchids are terrestrial and the great majority of these grow on the forest floor. In contrast, in Orchidaceae as a whole, around 75\% of the species are epiphytes, which demonstrates 
the strong correlation between a terrestrial lifestyle and variegation in orchids. It seems plausible that most cases of variegation represent defensive colouration, either as camouflage, mimicry or aposematic colouration. In several variegated species, plain green individuals may grow intermixed with variegated ones, which suggests that negative frequency-dependent selection may occur. Very few field studies have been carried out on variegated orchids and it is safe to say that this is a neglected topic in orchid ecology.

\section{Acknowledgements}

I am grateful to Phillip Cribb, Stig Dalström, Johan Hermans, the late Rudolf Jenny, Peter Jongejan, Henry Oakeley, Fanie Venter, and the late Peter O'Byrne for allowing me to use their excellent photographs for this paper. I thank the Hortus botanicus, Leiden, the Royal Botanic Gardens, Kew, Roy Barrow, the late Michael Mclllmurray, Laurent Minet, and Terry Want for enabling me to photograph plants from their collections. Some of my photographs reproduced here were made in the field, and I am much indebted to the support from the Director of the Department of Terrestrial Protected Areas, Ministry of Environment, Cambodia, Dr Keo Omaliss of the Cambodia Forestry Administration, and to Prof Charlie Heatubun and Jimmy Frans Wanma of UNIPA, Manokwari, West Papua Province, Indonesia, as well as LIPI, Bogor, Indonesia. Sulistiyono showed me populations of Anoectochilus reinwardtii and Macodes petola in Java. Simcha Lev-Yadun kindly provided some of his publications. The BenthamMoxon Trust funded part of this fieldwork. I thank the reviewers for helpful criticisms and comments.

\section{APPENDIX - list of Orchidaceae with variegated leaves}

The following descriptive code is used: $\mathbf{B}$ - leaf with blotches delimited or guided by veins; G leaf plain green, not variegated; L - leaf with longitudinal bands of a different colour; $\mathbf{N}$ - ground colour of the leaf not green; $\mathbf{S}$ - leaf with spots independent of the veins; $\mathbf{V}$ - leaf with veins that are strikingly darker or lighter or of a different colour; '/' means 'or', to indicate that two different kinds of variegation are known to exist within the species, or that both variegated and plain green leaves may occur. See main text for a more detailed explanation of the various categories. For species authorities, see Govaerts et al. (2021); they have here been omitted in the interest of legibility.

Acianthera crinita (S), A.dodsonii (S), A.gracilisepala (S), A. leptotifolia (S), A. melanochthoda (S), A. nikoleae (S), A. serratifolia (S), A. testifolia (S), Aenhenrya rotundifolia (BL), Aerangis punctata (S), Anathallis humilis (S), A. imbricata (S), A. vitorinoi (S), A. welteri (S), Andinia auriculipetala (V), A. catella $(\mathrm{V})$, A. chaoae (V), A. composita (V), A. cordilabia (V), A. exigua (V), A. hernandoi (V), $A$. hippocrepica (V), A. irrasa (V), A. micropetala (V), $A$. monilia $(\mathrm{V}), A$. montis-rotundi $(\mathrm{V}), A$. ortiziana $(\mathrm{V})$, A. persimilis (V), A. pilosella (V), A. platysepala (V), A. pseudocaulescens (V), A. sibundoyensis (V), A. vieira-pereziana (V), A. werneri (V), Angraecum urschianum (S), Anoectochilus albolineatus (NV), A. albomarginatus (NV), A. annamensis (NV), $A$. baotingensis (NV), A. brevilabris (NV), A. burmannicus (NV), A. calcareus (NV), A. dewildeorum (NV), $A$. dulongensis (NV), A. elatus (NV), A. emeiensis (NV), A. falconis (NV), A. flavescens (NV), A. formosanus (NV), A. geniculatus (NV), A. hainanensis (NV), $A$. imitans (NV), A insignis (NV), A. integrilabris (NV), A. kinabaluensis (NV), A. klabatensis (NV), $A$. koshunensis (NV), A. longicalcaratus (NV), A. longilobus (NV), A. lylei (NV), A. malipoensis (NV), A. monicae (NV), A. nandanensis (NV), $A$. narasimhanii (NV), A. nicobaricus (NV), A. papillosus (NV), A. papuanus (NV), A. pectinatus (NV), $A$. pingbianensis $(\mathrm{NV}), A$. regalis $(\mathrm{NV}), A$. reinwardtii (NV), A. rhombilabius (NV), A. roxburghii (NV/ $\mathrm{BNV}), A$. sanguineus (N), A. setaceus (NV), $A$. subregularis (NV), A. sumatranus (NV), A.tetrapterus $(\mathrm{V})$, A. xingrenensis (NV), A. yatesiae (NV), $A$. zhejiangensis (NV), Bidoupia khangii (NV), B. phongii (NV), Bulbophyllum caput-gnomonis (V), B. deuterodischorense (V), B. lygeron (V), B. reticulatum 
(V), Calanthe argenteostriata (L), C. crenulata (S), C. maxii (S), C. woodfordii (S/G), Cheirostylis bidentata (LV), C. clibborndyeri (LV), C. cochinchinensis (L), C.goldschmidtiana (N), C.griffithii (LN), C. marmorifolia (NV), C. montana (NV), C. nantouensis (N), C. ovata (LV), C. parviflora (LN), C. rubrifolia (N), C. spathulata (NV), C. thailandica (LNV), C. tortilacinia (N), C. yunnanensis (L), Coccineorchis navarrensis (LS/G), Coelogyne bruneiensis $(\mathrm{N})$, C. incrassata $(\mathrm{N})$, C. monilirachis $(\mathrm{N})$, C. renae $(\mathrm{N})$, Collabium acuticalcar $(\mathrm{S}), C$. bicameratum (S), C. carinatum (S), C. chapaense (S), C. chinense (S), C. delavayi (S), C. formosanum (LS), C. nebulosum (S), C. ovalifolium (S), C. simplex (S), C. vesicatum (S), C. yunnanense (S), Corybas acuminatus (V/G), bancanus (V), C. boholensis (V), C. boridiensis (V), C. calcicola (V), C. callifer (V), C. calophyllus (NV), C. circinatus (V), C. crenulatus (V), C. cyclopensis (N), C. cymatilis (V), C. ecarinatus (NV), C. erythrocarpus (V), C. finisterreanus (V/G), C. fornicatus (V), C. geminigibbus (V), C. gemmatus (V), C. helensis (NV), C. holttumii (V), C. imperatorius (V), C. karkarensis (NV), C. koresii (V), C. laceratus (V), C. leucotyle (V), C. mammillifer (NV), C. mankiensis (V), C. montis-stellare (V), C. pictus (V), C. praetermissus $(\mathrm{V})$, C. puberulus $(\mathrm{V})$, C. ramosianus (V), C. roseus (V), C. royenii (V), C. sagittatus (V), C. scutellifer (V), C. selangorensis (V), C. serpentinus (V), C. simbuensis (NV), C. smithianus (V), C. solomonensis (NV), C. speculum (V), C. stenotribonos (V), C. striatus (V), C. subalpinus (V/G), C. torricellensis (N), C. umbonatus $(\mathrm{V})$, C. viridisepalus (V), Cranichis diphylla (B), C. gracilis (NV), C. hieroglyphica (NV), C. sylvatica (NV), C. turkeliae (L), Cremastra unguiculata (S), Crepidium amabile (L), C. amplectens (LN), C. andersonii (L), C. atratum $(\mathrm{N})$, C. binabayense $(\mathrm{N})$, C. brachyodontum $(\mathrm{N}), C$. calophyllum (LV), C. chlorophrys (LN), C. clemensii (L), C. comberi (N), C. cupreum (N), C. decumbens (V/G), C.discolor (N/G), C. fasciatum (LN), C. fissum (N), C.godefroyi (N/G), C. graciliscapum (N), C. hoi (LN), C. hydrophilum (N), C. josephianum (N), C. khasianum (N), C. lamii (N), C. latum (N), C. leucodon (N), C. lowii (LN), C. luniferum (N), C. maculatum (S), C. merapiense (N/G), C. metallicum
(N), C. micranthum (LN/N), C. nigrescens (N), C. obovatum (LN), C. oculatum (N), C. oreocharis (N), C. paguroides $(\mathrm{N})$, C. partitilobum $(\mathrm{L})$, C. pleistanthum (N/G), C. punctatum (S), C. purpureonervosum (V), C. purpureum (N/G), C. rajanum (L), C. rhabdophyllum (LN), C. seychellarum (N), C. soleiforme (L), C. stenostachys $(\mathrm{N})$, C. sublobatum $(\mathrm{S})$, C. venosum (LN), C. woodianum (N), Cryptostylis acutata (V), C. arachnites (V), C. ovata (V), C. taiwaniana (SV), Cyclopogon alexandrae (S), C. argyrifolius (L), C. argyrotaenius (L), C. calophyllus (L), C.chloroleucus (L), C.comosus (L), C.cranichioides (S), C. elatus (L), C. elegans (L), C. epiphyticus (LSN), C. hennisianus (L), C. hirtzii (S), C. inequilaterus (S), C. lindleyanus (L), C. longibracteatus (L), C. miradorensis (L), C. olivaceus (NS), C. pelagalloanus (L), C. subalpestris (S), C. trifasciatus (L), C. truncatus (L), C. variegatus (NS), C. vittatus (L), C. williamsii (N), Cynorkis aconitiflora (S), C. coccinelloides (BV), C. elegans (B), C. elephantina (S), C. gibbosa (S), C. jackyi (BV), C. kassneriana (V/G), C. lentiginosa (S), C. marmorata (B), C. peyrotii (BV), C. purpurea (S/ $\mathrm{G})$, C. ridleyi (NSV), C. sororia (V), C. uniflora (S/ $\mathrm{G})$, Cypripedium fargesii (S), C. forrestii (S/G), C. lentiginosum (S), C. lichiangense (S), C. margaritaceum (S), C. wumengense (S), Cystorchis appendiculata $(\mathrm{N})$, C. celebica $(\mathrm{N})$, C. dentifera $(\mathrm{N})$, C. javanica $(\mathrm{N})$, C. luzonensis (N), C. macrophysa (BN), C. marginata $(\mathrm{N})$, C. ogurae (NV), C. orphnophila $(\mathrm{N})$, C. ranaiensis $(\mathrm{N})$, C. saccosepala (BV), C. stenoglossa $(\mathrm{N})$, C. variegata $(\mathrm{B} / \mathrm{N})$, C. versteegii $(\mathrm{N})$, Dactylorhiza aristata (S), D. euxina (S), D. incarnata (S/G), D. maculata (S), D. majalis (S/G), Diglyphosa latifolia $(\mathrm{S} / \mathrm{G})$, Disa aemula (S), D. cornuta (S), D. fasciata (S), D. fragrans (S/G), Disperis cordata (V), D. erucifera $(\mathrm{V})$, D. fayi $(\mathrm{V})$, D. hildebrandtii $(\mathrm{V}), D$. johnstonii (V), D. katangensis (V), D. leuconeura (V), D. neilgherrensis (NV), D. oppositifolia (V), D. reichenbachiana $(\mathrm{V})$, D. similis $(\mathrm{V})$, D. thorncrof tii $(\mathrm{SV})$, D. togoensis $(\mathrm{V})$, D. trilineata $(\mathrm{V})$, D. tripetaloides $(\mathrm{V})$, D. woodii (V), Domingoa gemma (S), D. purpurea (S), Dossinia marmorata (V), Dracomonticola virginea (V), Dryadella guatemalensis (S), D. liliputiana (S), Ephippianthus sachalinensis (V), Epidendrum escobarianum (S), E. tovarense (S), 
Eulophia analamerensis (S), E. analavelensis (S), E. antsingyensis (NS), E. bosseriana (NS), E. calcarata (S), E. decaryana (NS), E. hebdingiana (NS), E. lanceata (S), E. latifolia (S), E. lubbersiana (S), E. maculata (S), E. perrieri (S), E. peyrotii (NS), E. rauhii (NS), E. roseovariegata (NS), E. schlechteri (S), E. spathulifera (BNSV), E. splendida (S), Eurycentrum obscurum (BN), E. salomonense (NV), Galearis roborovskii (S/ $\mathrm{G})$, Gastrochilus acinacifolius (S), G. affinis (S), G. alatus (S), G. ciliaris (S), G. deltoglossus (S), G. distichus (S), G. fuscopunctatus (S), G. gongshanensis (S), G. guangtungensis (S), G. hoi (S), G. kadooriei (S), G. matsudae (S), G. matsuran (S), G. minutiflorus (S), G. nanchuanensis (S), G. nanus (S), G. prionophyllus (S), G. pseudodistichus (S), G. rantabunensis (S), G. raraensis (S), G. sinensis (S), G. toramanus (S), G. yunlongensis (S), Gonatostylis vieillardii (BV/N), Goodyera alveolata (V), G. amoena (V), G. beccarii (B), G. biflora (LV), G. brachystegia (V), G. bradeorum (V), G. clausa (V), G. colorata (V), G. crocodiliceps (L), G. cyclopensis (NV), G. daibuzanensis (BL), G. elmeri (V), G. erosa (L), G. fimbrilabia (L), G. gemmata (NV), G. gibbsiae (V), G. hachijoensis (V), G. hemsleyana (V), G. hispida (V), G. inmeghema (V), G. kwangtungensis (BV), G. lamprotaenia $(\mathrm{V}), \mathrm{G}$. luzonensis $(\mathrm{N}), \mathrm{G}$. malipoensis (LV), G. marginata (LV), G. nankoensis (L), G. nanshanensis (BV), G. nantoensis (V), G. oblongifolia (V), G. ovatilabia (V), G. porphyrophylla (N), G. pubescens (V), G. pusilla (NV), G. ramosii (V), G. repens $(\mathrm{V})$, G. reticulata $(\mathrm{V})$, G. rhombodoides $(\mathrm{L}), \mathrm{G}$. rostellata (V), G. ruttenii (V), G. schlechtendaliana (BV), G. similis (V), G. stenopetala (V), G. striata (BV), G. sumbawana (N), G. tesselata (V), G. venusta (V), G. vittata (L/V), G. wuana (V), G. yunnanensis (V), Gravendeelia chamaelepanthes (V), Habenaria aitchisonii $(\mathrm{BV})$, H. arenaria $(\mathrm{B} / \mathrm{G})$, H. carnea (NLS/ $\mathrm{NS} / \mathrm{S}), H$. diplonema (V), $H$. fargesii (B), $H$. rhodocheila (NS), H. tibetica (LV), H. trilobulata (NV), H. wolongensis (V), Hemipilia brevicalcarata (LV), H. calophylla (V), H. cordifolia (S), H. flabellata (S/ $\mathrm{G})$, H. galeata (S), H. henryi (S), H. kwangsiensis (S), H. occidensichuanensis (S/G), H. purpureopunctata (S), Holothrix orthoceras (V), Homalopetalum kienastii (S), Kuhlhasseltia gillesii (N), K. gracilis (N/G), K. javanica $(\mathrm{N})$, K. papuana $(\mathrm{N})$, Lepanthes aguirrei
(V), L. barbellata (V), L. bibarbullata (V), L. calodictyon (V), L. calophlebia (V), L. dictydion (V), L. dodsonii (V), L. fiskei (N), L. gargoyla (N), L. hexapus (V), L. mastodon $(\mathrm{N})$, L. maxillaris $(\mathrm{V})$, L. melpomene $(\mathrm{N})$, L. niesseniae $(\mathrm{N})$, L. ova-rajae $(\mathrm{V})$, L. papyrophylla $(\mathrm{N})$, L. posthon $(\mathrm{V})$, L. reticulata $(\mathrm{V})$, L. rhodophylla $(\mathrm{N})$, L. saltatoria $(\mathrm{V})$, L. satyrica $(\mathrm{V})$, L. tentaculata $(\mathrm{V})$, L. terpsichore $(\mathrm{N})$, L. tetrapus $(\mathrm{V})$, L. tomentosa $(\mathrm{N})$, L. vanbalenii $(\mathrm{N})$, L. volador $(\mathrm{V})$, L. volvox $(\mathrm{V})$, Liparis cordifolia (L), L. kamborangensis (V), L. purpureoviridis (NV), Ludisia discolor (NV), Macodes angustilabris (V), M. celebica (V), M. cominsii (V), M. cupida (V), M. dendrophila (N), $M$. limii (V), M. megalantha (V), M. obscura (L), M. petola (V), M. pulcherrima (NV), M. sanderiana (NV), Macroclinium aurorae (S), M. dalessandroi (S), $M$. dalstroemii (S), M. generalense (S), M. glicensteinii (S), M. lexarzanum (S), M. manabinum (S), M. ramonense (S), M. robustum (S), M. wullschlaegelianum (S), M. xiphophorus (S), Manniella gustavi (B), Maxillaria pseudoreichenheimiana (S), M. reichenheimiana (S), Mesadenella cuspidata (S), M. esmeraldae (S), M. variegata (LS), Mesadenus lucayanus (V/G), Microchilus alajuelae (B), M. anchorifer (BL), $M$. $\operatorname{argenteus}(\mathrm{V})$, M. arietinus (L), M. bidentiferus (L), M. bruxellii (L), M. calophyllus (B), M. constrictus (V), M. curviflorus subsp. azulitae (V), M. decorus (L), M. ecuadorensis (B), M. ensicalcar (V), M. erythrodoides (B), M. fendleri (B), M. fimbrillaris (LV), M. grayumii (B), M. jamesonii (B), M. julianii (B), M. killipii (L), M. kuczynskii (LV), M. longibracteatus (L), $M$. leucostictus (V), M. lunifer (B), M. madrinanii (B), M. major (B), M. mosaicus (B), M. mystacinus (BN), M. nigrescens (B), M. ortgiesii (BL), M. popayanensis (V), M. preslii (L), M. procerus (B), M. pumilus (V), $M$. rariflorus $(\mathrm{L})$, M. querceticola $(\mathrm{B} / \mathrm{G})$, M. rioesmeraldae (V), M. rioitayanus (B), M. roseoalbus (L), M. sororius (L), M. sparsiflorus (L), M. sprucei (L), M. stictophyllus (B), M. tesselatus (B), M. tridax (BN/N), M. trifasciatus (B), M. valverdei (B), M. vesicifer (B), $M$. whitefoordiae (B), M. xystophyllus (V), M. zonatus (L), Monophyllorchis microstyloides (V), Neotinea maculata (S), Nephelaphyllum aureum (LNV), N. beccarii (BL), N. cordifolium (BLV), N. flabellatum (BL), N. maliauense (BLNV), N. mindorense (BL), 
N. pulchrum (BLN), N. tenuiflorum (BV), N. thaovyae (BLN), N. trapoides (B), N. verruculosum (BN), Nervilia adolphi (BLV/G), N. ballii (V), N. concolor $(\mathrm{B} / \mathrm{G}), N$. fuerstenbergiana $(\mathrm{BL}), N$. infundibulifolia (L), N. khaoyaica (N/G), N. maculata (S), N. marmorata (LNV), N. multinervis (BN), N. nipponica (BNV), N. pangteyana (L), N. platychila (S/G), N. plicata (NS/N), N. stolziana (V/G), N. taitoensis $(\mathrm{BNV}), \mathrm{N}$. trangensis $(\mathrm{NV} / \mathrm{G})$, Oberonia cavaleriei (S), Odontochilus buruensis (V), O. coerulescens (V/ $\mathrm{G})$, O. elwesii (N), O. hatusimanus (V), O. lanceolatus $(\mathrm{V})$, O. marivelensis (V), O. pumilus (V), O. quadrilobatus $(\mathrm{V})$, Orchis italica (S/G), O. mascula $(\mathrm{S} / \mathrm{G})$, O. provincialis (S/G), O. quadripunctata (S), Pabstiella itaguacuensis (S), leucopyramis (S), Pachyplectron arifolium (BN), P. neocaledonicum (N), Paphiopedilum acmodontum (BV), P. agusii (BV), P. appletonianum (BV), P. argus (BV), P. armeniacum (BV), P. barbatum (BV), P. bellatulum (BV), P. bullenianum (BV), P. bungebelangi (BV), P. callosum (BV), P. canhii (BV), P. ciliolare (BV), P. concolor (BV), P. dayanum (BV), P. delenatii (BV), P. dodyanum (BV), P. fowliei (BV), P. godefroyae (BV), P. hennisianum (BV), P. inamorii (BV), P. jackii (BV), P. javanicum (BV), P. lawrenceanum (BV), P. liemianum (BV), P. lunatum (BV), P. malipoense (BV), P. mastersianum (BV), P. micranthum (BV), P. myanmaricum (BV), P. nataschae (BV), P. niveum (BV/G), P. papuanum (BV), P. parnatanum (BV), P. purpuratum (BV), P. robinsonianum (BV), P. rohmanii (BV), P. rungsuriyanum (BV), P. sangii (BV), P. schoseri (BV), P. sugiyamanum (BV), P. sukhakulii (BV), P. superbiens (BV), P. thaianum (BV), P. tonsum (BV), P. urbanianum (BV), P. venustum (BV), P. vietnamense $(\mathrm{BV})$, P. violascens $(\mathrm{BV})$, P. wardii $(\mathrm{BV})$, $P$. wenshanense (BV), P. wentworthianum (BV), P. zulhermanianum (BV), Papillilabium beckleri (S), Papuaea reticulata (V), Pelexia adnata (B/G), P. callifera (BN/LN/N), P. decora (B), P. ecuadorensis (B), P. funckiana (S/G), P. goninensis (N), P. laxa (NS), P. lindmanii (S/G), P. maculata (S), P. novofriburgensis (S), P. olivacea (L), P. sancta (N), Phalaenopsis celebensis (NS), P. lindenii (NS), P. philippinensis (NS), P. pulcherrima var. marmorata (NS), P. schilleriana (NS), P. stuartiana (NS), Platanthera orbicularis (V),
Plocoglottis javanica (S), P. lowii (N), P. plicata (L/S/G), Ponerorchis cucullata (S/G), P. physoceras (S), Ponthieva garayana (L), Porpax jerdoniana (BV), Prescottia stachyodes (L/G), Pseudogoodyera wrightii (V), Psychopsiella limminghei (NS), Psychopsis kramerianum (NS), P. papilio (NS), P. sanderae (NS), P. versteegiana (NS), Pteroglossa euphlebia (S), P. roseoalba (S), Quekettia microscopica (S), Q. papillosa (S), Q. peruviana (B), Q.pygmaea (B), Q.vermeuleniana (B), Rhomboda abbreviata (V), R. alticola (V), R. atrorubens (NV), R. blackii (V), R. cristata (NV), R. dennisii $(\mathrm{V}), R$. fanjingensis $(\mathrm{V}), \mathrm{R}$. lanceolata $(\mathrm{V}), R$. minahassae $(\mathrm{NV}), R$. moulmeinensis $(\mathrm{V}), R$. pauciflora $(\mathrm{V})$, R.petelottii $(\mathrm{V})$, R. polygonoides $(\mathrm{NV})$, R. pulchra $(\mathrm{NV})$, R. tokioi $(\mathrm{V})$, R. velutina $(\mathrm{V})$, R. yakusimensis $(\mathrm{V})$, Rhynchostylis gigantea (V), R. retusa (V), R. rieferi (V), Robiquetia honhoffii (S), R. punctata (S), Saccolabiopsis armitii (S), Sacoila lanceolata (V), Sarcochilus ceciliae (S), S. hillii (S), S. rarus (S), S. spathulatus (S), Sarcoglottis acaulis (S/G), S. cerina (S), S. grandiflora (S), S. hunteriana (L), S. latifolia (S), S. maasorum (N), S. maroaense (S), S. metallica (NS), S. powelii (S/G), S. rosulata (L), S. sceptrodes (LS), S. schaffneri (S), S. stergiosii (S), Scaphyglottis dunstervillei (S), Schistotylus purpuratus (S), Sirindhornia mirabilis (S), S. monophylla (S), S. pulchella (S), Specklinia grobyi (S), S. pisinna (S), Stelis resupinata $(\mathrm{S})$, Stenoglottis fimbriata $(\mathrm{S} / \mathrm{G})$, S. inandensis $(\mathrm{S} / \mathrm{G})$, S. longifolia $(\mathrm{S} / \mathrm{G})$, Stenorrhynchos albidomaculatum (S), S. austrocompactum (LS), S. glicensteinii (L/G), S. speciosum (LS/G), Tainia cordifolia (S), T. marmorata (S), purpureifolia (N), Teagueia alyssana (V), Tipularia discolor (S/G), T. odorata (S), Trichocentrum albococcineum (S), T. andreanum (S), T. candidum (S), T. carthagenense (S), T. lanceanum (S), T. lindenii (S), T. loyolicum (S), T. moreniorum (S), T. morenoi (S), T. nanum (S), T. nataliae (S), T. pulchrum (S), T. pumilum (S), T. pupulinianum (S), T. schwambachiae (S), T. tigrinum (S), T. undulatum (S), Trisetella cordeliae $(\mathrm{S}), T$. regia $(\mathrm{S})$, Vrydagzynea albida (V/G), V. albostriata (V), V. $\operatorname{argentistriata}(\mathrm{V})$, V. argyrotaenia $(\mathrm{L}), V$. celebica $(\mathrm{V})$, V.deliana $(\mathrm{V})$, V. lancifolia $(\mathrm{L}), V$. micronesiaca $(\mathrm{V})$, 
$V$. pauciflora $(\mathrm{V}), V$. purpurea $(\mathrm{NV}), V$. tilungensis $(\mathrm{V}), V$. tristriata $(\mathrm{NV}), V$. vitiensis $(\mathrm{V}), V$. vrydagzynoides $(\mathrm{L})$, Zeuxine amboinensis $(\mathrm{N}), Z$. blatteri (L), Z. glandulosa (N), Z. goodyeroides (NV/ $\mathrm{V} / \mathrm{N})$, Z. integrilabella $(\mathrm{V})$, Z. nervosa (L), Z. parvifolia (L/G), Z. philippinensis (LV), Z. purpurascens (V), Z. regia $(\mathrm{LN}), Z$. reginasilvae $(\mathrm{LN}), Z$. vietnamica $(\mathrm{N})$, $Z$. violascens $(\mathrm{NV}), Z$. weberi $(\mathrm{N})$.

\section{Literature Cited}

BHL 2021. Biodiversity Heritage Library. Available at: https:/ /www.biodiversitylibrary.org/. (Accessed on 24.03.2021)

BRODERSEN C.R. \& T.C. VOGELMANN 2007. Do epidermal lens cells facilitate the absorptance of diffuse light? American Journal of Botany 94: 1061-1066.

CAMPITELLI B.E., STEHLIK I. \& J.R. STINCHCOMBE 2008. Leaf variegation is associated with reduced herbivore damage in Hydrophyllum virginianum. Botany 86: 306-313. https://doi.org/10.1139/B07-139

CHASE M.W., CHRISTENHUSZ M.J.M. \& A. SCHUITEMAN 2020. Expansion of Calanthe to include the species of Cephalantheropsis, Gastrorchis and Phaius (Collabieae; Orchidaceae). Phytotaxa 472: 159-168. https://doi.org/10.11646/phytotaxa.472.2.6

CHASE M.W., SCHUITEMAN A. \& P. KUMAR 2021. Expansion of the orchid genus Eulophia (Eulophiinae; Epidendroideae) to include Acrolophia, Cymbidiella, Eulophiella, Geodorum, Oeceoclades and Paralophia. Phytotaxa 491: 47-56. https://doi.org/10.11646/ phytotaxa.491.1.5

CUTHILL I.C., STEVENS M., SHEPPARD J., MADDOCKS T., PÀRRAGA C.A. \& T.S. TROSCIANKO 2005. Disruptive coloration and background pattern matching. Nature 434: 72-74. https:/ /doi.org/10.1038/nature03312

DRESSLER R.L. 1981. The Orchids: Natural History and Classification. Harvard University Press, Cambridge, Massachusetts and London.

ESTEBAN R., FERNÀNDEZ-MARÍN B., BECERRILJ.M. \& J.I. GARCÍA-PLAZAOLA 2008. Photoprotective implications of leaf variegation in E. dens-canis L. and $P$. officinalis L. Journal of Plant Physiology 165: 1255-1263. https://doi.org/10.1016/j.jplph.2007.07.024

GIGORD L.D.B., MACNAIR M.R. \& A. SMITHSON 2001. Negative frequency-dependent selection maintains a dramatic flower color polymorphism in the rewardless orchid Dactylorhiza sambucina (L.) Soó.
Proceedings of the National Academy of Sciences 98: 62536255. https://doi.org/10.1073/pnas.111162598

GOULD K.S., NEILL S.O. \& T.C. VOGELMANN 2002. A unified explanation for anthocyanins in leaves? Advances in Botanical Research 37: 167-192.

GOVAERTS R., BERNET P., KRATOCHVIL K., GERLACH G., CARR G., ALRICH P., PRIDGEON A.M., PFAHL J., CAMPACCI M.A., HOLLAND BAPTISTA D., TIGGES H., SHAW J., CRIBB P., GEORGE A., KREUTZ K. \& J.J. WOOD 2021. World Checklist of Orchidaceae. Facilitated by the Royal Botanic Gardens, Kew. Available at: http://wcsp.science. kew.org/. (Accessed on 26.05.2021)

GROIß A.M., BRAUN A., GREIMLER J. \& M. KROPF 2017. Pollen tracking in the food-deceptive orchid Dactylorhiza sambucina showed no predominant switching behaviour of pollinators between flower colour morphs. Flora 232: 194-199. https://doi.org/ 10.1016/j.flora.2017.02.021

HARA N. 1957. Study of the variegated leaves, with special reference to those caused by air spaces. Japanese Journal of Botany 117: 86-101.

HUGHES N.M., GIGANTINO G.M., GRACE M.H., HOFFMAN K.M., LILA M.A., WILLANS B.N. \& A.J. WOMMACK 2019. Photosynthetic profiles of green, purple, and spotted-leaf morphotypes of Tipularia discolor (Orchidaceae). Southeastern Naturalist 18: 641-658. https://doi.org/10.1656/058.018.0415

KÜHN R., PEDERSEN H.Æ. \& P. CRIBB 2019. Field Guide to the Orchids of Europe and the Mediterranean. Royal Botanic Gardens, Kew, Richmond.

LA ROCCA N., PUPILLO P., PUPPI G. \& N. RASCIO 2014. Erythronium dens-canis L. (Liliaceae): an unusual case of change of leaf mottling. Plant Physiology and Biochemistry 74: 108-117. https://doi.org/10.1016/ j.plaphy.2013.11.005

LA ROCCA N., RASCIO N. \& P. PUPILLO 2011. Variegation in Arum italicum leaves. A structuralfunctional study. Plant Physiology and Biochemistry 49: 1392-1398. https://doi.org/10.1016/j.plaphy.2011.09.009

LEV-YADUN S. 2014. Potential defence from herbivory by 'dazzle effects' and 'trickery coloration' of leaf variegation. Biological Journal of the Linnean Society 111: 692-697. https://doi.org/10.1111/bij.12251

LEV-YADUN S. 2016. Defensive (anti-herbivory) Coloration in Land Plants. Anti-Herbivory Plant Coloration and Morphology. Springer International Publishing, Switzerland. https://doi.org/10.1007/978-3-319-42096-7

PEMBERTON R.W. 2013. Pollination of slipper orchids (Cypripedioideae): a review. Lankesteriana 13: 65-73. https://doi.org/ 10.15517/lank.v0i0.11539 
POOBATHY R., ZAKARIA R., MURUGAIYAH V. \&

S. SUBRAMANIAM 2018. Autofluorescence study and selected cyanidin quantification in the jewel orchids Anoectochilus sp. and Ludisia discolor. PLoS ONE 13: art. e0195642. https://doi.org/10.1371/ journal.pone. 0195642

POWO 2021. Plants of the World Online. Available at: http:/ /www.plantsoftheworldonline.org/. (Accessed on 24.03.2021).

REN Z.X., LI D.Z., BERNHARDT P. \& H. WANG 2011. Flowers of Cypripedium fargesii (Orchidaceae) fool flat-footed flies (Platypezidae) by faking fungusinfected foliage. Proceedings of the National Academy of Sciences 108: 7478-7480. https://doi.org/ 10.1073/ pnas. 1103384108

REN Z.X, LI D.Z., BERNHARDT P. \& H. WANG 2012. Correction for "Flowers of Cypripedium fargesii (Orchidaceae) fool flat-footed flies (Platypezidae) by faking fungus-infected foliage". Proceedings of the National Academy of Sciences 109: 20776. https://doi.org/ 10.1073/pnas.1219348110

SHEUE C.R., PAO S.H., CHIEN L.F., CHESSON P. \& C.I. PENG 2012. Natural foliar variegation without costs? The case of Begonia. Annals of Botany 109: 10651074. https://doi.org/10.1093/aob/mcs025
SMIDT E.C., SALAZAR G.A., SILVÉRIO RIGHETTO MAUAD A.V., ENGELS M.E., VIRUEL J., CLEMENTS M., JIMÉNEZ PÉREZ I. \& M.W. CHASE 2021. An Indomalesian origin in the Miocene for the diphyletic New World jewel orchids (Goodyerinae, Orchidoideae): molecular dating and biogeographic analyses document non-monophyly of the Neotropical genera. Botanical Journal of the Linnean Society: boab028. https://doi.org/10.1093/botlinnean/ boab028

SOLTAU U., DÖTTERL S. \& S. LIEDE-SCHUMANN 2009. Leaf variegation in Caladium steudnerifolium (Araceae): a case of mimicry? Evolutionary Ecology 23: 503-512. https://doi.org/10.1007/s10682-008-9248-2

VERMEULENJ.J., SCHUITEMAN A. \& E.F. DE VOGEL 2017. New taxa in Bulbophyllum (Orchidaceae: Epidendroideae: Malaxideae) from New Guinea, lifting a mega-genus over the 2000-species mark. Malesian Orchid Journal 21: 31-68.

ZHANG J.H., ZENG J.C., WANG X.M., CHEN S.F., ALBACH D.C. \& H.Q. LI 2020. A revised classification of leaf variegation types. Flora 272: 151703. https:// doi.org/10.1016/j.flora.2020.151703 